Southern Illinois University Carbondale

OpenSIUC

Publications

Center for Fisheries, Aquaculture, and Aquatic

Sciences

$10-2016$

\title{
Population-Level Responses of Life History Traits to Flow Regime in Three Common Stream Fish Species
}

Micah G. Bennett

Matt R. Whiles

Southern Illinois University Carbondale

Gregory Whitledge

Southern Illinois University Carbondale, gwhit@siu.edu

Follow this and additional works at: http://opensiuc.lib.siu.edu/fiaq pubs

\section{Recommended Citation}

Bennett, Micah G., Whiles, Matt R. and Whitledge, Gregory. "Population-Level Responses of Life History Traits to Flow Regime in Three Common Stream Fish Species." Ecohydrology 9, No. 7 (Oct 2016): 1388-1399. doi:10.1002/eco.1734.

This Article is brought to you for free and open access by the Center for Fisheries, Aquaculture, and Aquatic Sciences at OpenSIUC. It has been accepted for inclusion in Publications by an authorized administrator of OpenSIUC. For more information, please contact opensiuc@lib.siu.edu. 


\section{Population-level responses of life history traits to flow regime in three common stream fish species}

Article in Ecohydrology · February 2016

DOI: $10.1002 /$ eco.1734View

CITATIONS

0

3 authors, including:

Micah G Bennett

United States Environmental Protection Agency

17 PUBLICATIONS 10 CITATIONS

SEE PROFILE
READS

64

Gregory W Whitledge

Southern Illinois University Carbondale

84 PUBLICATIONS 952 CITATIONS

SEE PROFILE

Some of the authors of this publication are also working on these related projects: 


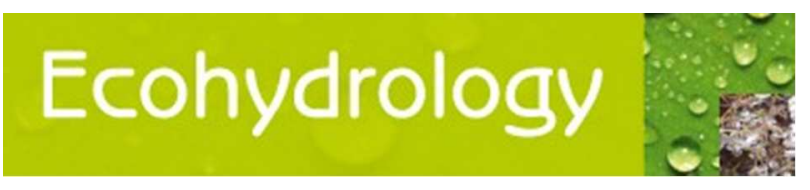

\section{Population-level responses of life history traits to flow regime in three common stream fish species}

\begin{tabular}{|r|l|}
\hline Journal: & Ecohydrology \\
\hline Manuscript ID & ECO-15-0148.R2 \\
\hline Wiley - Manuscript type: & Research Article \\
\hline Date Submitted by the Author: & 08-Feb-2016 \\
\hline Komplete List of Authors: & $\begin{array}{l}\text { Bennett, Micah; Southern Illinois University, Department of Zoology and } \\
\text { Center for Ecology; U.S. Environmental Protection Agency, Office of } \\
\text { Research and Development } \\
\text { Whiles, Matt; Southern Illinois University, Department of Zoology and } \\
\text { Center for Ecology } \\
\text { Whitledge, Gregory; Southern Illinois University, Center for Fisheries, } \\
\text { Aquaculture, and Aquatic Sciences; Southern Illinois University, } \\
\text { Department of Zoology and Center for Ecology }\end{array}$ \\
\hline Keywords: & \begin{tabular}{l} 
flow-ecology relationships, reproduction, functional trait, trait-based \\
\hline
\end{tabular} \\
\hline
\end{tabular}

\section{SCHOLARONE"}

Manuscripts

This is the pre-final peer review version of the following article: [Bennett, M.G., M.R. Whiles, and G.W.Whitledge. In press. Population-level responses of life history traits to flow regime in three common stream fish species. Ecohydrology. DOI 10.1002/eco.1734], which has been published in final form at [http://onlinelibrary.wiley.com/doi/10.1002/ eco.1734/full]. This article may be used for non-commercial purposes in accordance with Wiley Terms and Conditions for Self-Archiving. 
1 Population-level responses of life history traits to flow regime in three common stream fish

2 species

3

4 Micah G. Bennett $^{1 *}$, Matt R. Whiles ${ }^{1}$, and Gregory W. Whitledge ${ }^{1,2}$

5

$6{ }^{1}$ Department of Zoology and Center for Ecology, Southern Illinois University, 1125 Lincoln

7 Drive (Mail Code 6501), Carbondale, Illinois 62901

8

$9{ }^{2}$ Center for Fisheries, Aquaculture, and Aquatic Sciences, Southern Illinois University, 1125

10 Lincoln Drive (Mail Code 6511), Carbondale, Illinois 62901

11

12 *author to whom correspondence should be addressed; email: micahgbennett@yahoo.com;

13 current address: U.S. Environmental Protection Agency, Office of Research and Development,

14 Washington, DC 20460 USA

15

16

17

18

19 Running head: Fish intraspecific flow-life history relationships

20 Keywords: flow-ecology, reproduction, trait-based, functional trait

21

22

23 


\section{ABSTRACT}

27 Trait-based approaches may improve understanding in ecology by linking environmental

28 variation to fitness-related characteristics of species. Most trait-environment studies focus on

29 assemblage-level relationships; yet intraspecific trait variation is important for community,

30 ecosystem, and evolutionary processes and has substantial implications for these approaches.

31 Assessing population-level trait-environment relationships could test the generality of trait

32 models while assessing intraspecific variation. We evaluated the generality of the trilateral life

33 history model (TLHM of Winemiller and Rose 1992: opportunistic, periodic, and equilibrium

34 endpoints) for fishes - a well-studied trait-environment model at the assemblage level - to

35 populations of three stream fishes in the Midwestern United States in relation to flow regime.

36 The TLHM adequately described major trade-offs in traits among populations in all species.

37 Some TLHM flow-based predictions were confirmed, with periodic traits (high fecundity)

38 favored at sites with greater flow seasonality and lower flow variability in two species, and

39 equilibrium traits (large eggs) in more stable flow conditions in two species. Size at maturity was

40 also inversely related to variability in one species. However, relationships contradicting the

41 TLHM were also found. Coupled with the explanatory power of the TLHM for populations,

42 supporting relationships suggest that synthesizing habitat template models with demographic life

43 history theory could be valuable. Trait-environment models that are well-supported at multiple

44 levels of biological organization could improve understanding of the impacts of environmental

45 change on populations and communities and the valuable ecosystem services that they support. 46 
47

48

49

50

51

52

53

54

55

56

57 environmental flow standards (McManamay et al., 2014).

58

59 relationships; yet population-level trait variation also has important implications for these

60

61

62 Cornwell, 2007; Albert et al., 2010), as well as the fundamental evolutionary processes of

63 adaptation and speciation (Darwin, 1861). Therefore, assessment of trait-environment

64 relationships at the population level could further test the generality of trait-based models while

65 also estimating intraspecific trait variability (Verberk et al., 2013). Here, we provide a field-

66 based evaluation of the generality of a trait-environment model that has been well-studied at the

67 assemblage level in populations of three widespread stream fishes in the Midwestern United

68 States. 
The trilateral life history model (TLHM), a trait-environment model developed for fishes

70 by Winemiller and Rose (1992), reflects trade-offs between juvenile survival, fecundity, and

71 generation time. The endpoints of the TLHM represent life history strategies that are selected for

72 under certain environmental conditions (Figure 1). The opportunistic strategy minimizes

73 generation time, which promotes rapid population growth and should be favored in highly

74 variable environments. The equilibrium strategy maximizes juvenile survival through large eggs

75 or parental care and should be favored under stable environmental conditions that promote

76 investment in few, well-provisioned offspring. The periodic strategy maximizes fecundity by

77 delaying reproduction until a larger size is reached and is favored under predictably variable or

78 highly seasonal environments where reproduction can coincide with favorable conditions.

79 Studies from across the globe have largely confirmed fish life history trait ordination along these

80 three axes (e.g., Vila-Gispert et al., 2002; Olden and Kennard, 2010) and have documented the

81 utility of the TLHM for predicting assemblage-level life history traits in relation to natural and

82 altered flow regimes (e.g., Olden and Kennard, 2010; Mims and Olden, 2012, 2013).

Although applied at the assemblage level, the TLHM is based on fundamental traits that

84 exhibit trade-offs and determine fitness of individuals and populations (for instance, generation

85 time is a fundamental component of basic population models; and fecundity and egg size often

86 exhibit trade-offs at individual and population levels; Wootton and Smith, 2014), suggesting that

87 it may also apply at the population level; however, few studies have investigated intraspecific

88 trait variation among fish populations in relation to hydrologic variability. The application of

89 simple models like the TLHM or other habitat template approaches (Southwood, 1988) does not

90 reflect the full complexity of factors affecting population life history and does not determine a

91 definitive mechanism for any relationships (Stearns, 1992). Yet such an application could prove 
92 useful in identifying potential selective environmental factors (Endler, 1986) in the absence of

93 the more detailed, but difficult-to-acquire, information on age-structured mortality required of

94 demographic life history theory (Stearns, 1992). Further, using population-level studies to

95 confirm or refute trends from assemblage-level studies could suggest the relative merits and

96 generality of the proposed mechanisms or assumptions underlying trait-environment

97 relationships.

98 Our specific objectives were to: 1) determine if population-level variation in life history

99 traits follows assemblage-level TLHM findings; and 2) determine if predictions of the TLHM in 100 relation to flow regime apply at the population level for three stream fish species. We

101 hypothesized that: 1) intraspecific variation would be oriented similarly to the assemblage-level 102 TLHM; and 2) hydrologic variability would influence life history traits of populations as 103 predicted by the TLHM. Specifically, we hypothesized that flow variability would promote 104 opportunistic traits (small size at maturity), that flow predictability/stability would promote 105 equilibrium traits (large egg size), and that flow seasonality would promote periodic traits (high 106 fecundity) (Table 1).

107 METHODS

108 Species selection

109 Three study species were selected based on broad geographic distributions in the Central 110 Lowlands of North America, potentially high relative abundances, and diverse ecologies: red 111 shiner (Cyprinella lutrensis; Family Cyprinidae), bluntnose minnow (Pimephales notatus;

112 Family Cyprinidae), and orangethroat darter (Etheostoma spectabile; Family Percidae). The red 113 shiner is a habitat generalist most abundant in low-gradient streams and rivers. This species 114 spawns adhesive eggs in gravel riffles from spring to fall, usually peaking in June-July in the 
115 Midwest (Robison and Buchanan, 1988). Most individuals are mature by their second summer

116 (Boschung and Mayden, 2004). The species is likely a fractional spawner, laying up to 19

117 clutches/season in captivity (Boschung and Mayden, 2004). The bluntnose minnow occupies

118 mid-water column and near-benthic areas and lays eggs in rock crevices where eggs are

119 protected by males. Females, mature by age one, are fractional spawners and produce up to 4200

120 eggs/season during late spring-summer (Boschung and Mayden, 2004). The orangethroat darter

121 inhabits runs, pools, and riffle margins and spawns in riffles, with eggs buried in gravel and

122 receiving no parental care; females may spawn with multiple males per season during spring-

123 early summer and are mature by age one (Etnier and Starnes, 1993; Pflieger, 1997). Based on

124 species-level trait data, all three species would be classified as relatively opportunistic strategists

125 within the TLHM, having relatively short generation time, although parental care by bluntnose

126 minnow makes it more closely affiliated with the equilibrium strategy (Winemiller and Rose,

127 1992; MGB, unpublished).

128 Site selection

129 We selected a set of 'reference' USGS stream gages (Falcone et al., 2010) that coincided with 130 probable locations of target species (see Appendix S1 for details). Final sampling locations

131 containing the target species were all within the Mississippi-Ohio River watershed (Figure 2;

132 Appendix S1). Of the sites sampled, we obtained reproductive individuals from seven

133 populations of red shiner, eight populations of orangethroat darter, and 14 populations of

134 bluntnose minnow (Appendix S1).

135 Hydrologic variables and measurement

136 Predictions of the TLHM focus on environmental variability, stability, and predictability.

137 Because of the importance of flow regime to stream ecosystems, communities, and populations, 
138 these predictions have largely been operationalized as variability, stability, and

139 predictability/seasonality of the flow regime in studies of stream fishes. We selected hydrologic

140 metrics that highlight these aspects based on two recent assemblage-level studies (Mims and

141 Olden, 2012, 2013) in order to compare results (Table 1). Annual coefficient of variation of daily

142 flow (annCV) and the high pulse count $(H P C)$ were used as measures of flow variability.

143 Colwell's flow predictability index (FlowPred; Colwell, 1974) and the base flow index (BFI)

144 were used as measures of flow predictability/stability. Flow constancy divided by predictability

145 (ConstPred; Colwell, 1974) and high pulse duration (HPD) were used as measures of flow

146 seasonality. Additionally, mean daily discharge (mean $Q$ ) was used to measure flow magnitude

147 due to previous findings of discharge-life history relationships (Table 1). All indices were

148 calculated using Indicators of Hydrologic Alteration software (Richter et al., 1996) based on

149 medians using all years of data with $<10$ missing days for each gage through 2012 , the year

150 prior to fish sampling (Appendix S1).

151 We evaluated two variables for additional influences on life history traits due to expected

152 relationships from the literature: latitude and genetic divergence (Appendix S2). Latitude is

153 correlated with temperature, ecosystem productivity, and other variables known to influence life

154 history evolution (e.g., Leggett and Carscadden, 1978; Fleming and Gross, 1990) and served as a

155 test of broader geographic patterns unrelated to flow regime. We decided whether to include

156 latitude in our models by assessing individual impact on traits prior to final model testing and

157 included it if significantly related to at least one life history trait for a species $(\mathrm{p}<0.05)$. Latitude

158 was included in bluntnose minnow and red shiner models based on significant regressions

159 (Appendix S2). Life history traits may also be influenced more by evolutionary history than local

160 environmental conditions (Stearns, 1992); therefore, we evaluated the effect of genetic 
161 divergence on traits for orangethroat darter using published cytochrome b gene data (Bossu et 162 al., 2013) and a Mantel test between raw genetic and life history distances (cf. Olden and 163 Kennard, 2010; see Appendix S2). Based on this test, genetic divergence was not significantly 164 related to life history differences among populations (Appendix S2). Detailed phylogeographic 165 information was unavailable for the other species so we used stream distance as a potential 166 correlate of genetic divergence. Mantel tests were also non-significant for the minnow species 167 (Appendix S2). Due to this apparent lack of phylogenetic signal, we did not correct for 168 evolutionary history in subsequent analyses (Diniz-Filho et al., 2012).

$169 \quad$ Fish sampling

170 Fishes were sampled from a $100 \mathrm{~m}$ reach within $1 \mathrm{~km}$ of USGS gage locations using a 171 seine (3.05 x $1.22 \mathrm{~m})$ and backpack electrofishing unit (Smith-Root LR-24, Vancouver, WA). 172 Sampling was aimed at study species and ceased when approximately 30 adult females of each 173 species were obtained or when several successive sampling efforts (seine hauls or seine with 174 electrofishing) produced no additional target individuals. Sampling occurred usually once 175 seasonally as appropriate to target peak spawning for study species (spring for orangethroat 176 darter, late summer for cyprinids). Most sites were sampled in 2013 or 2014, and sometimes in 177 both years in an attempt to obtain more mature individuals (Appendix S1). Fish were euthanized 178 using MS-222 (300 mg/L), fixed in 10\% formaldehyde, and transferred to $70 \%$ ethanol for 179 examination in the laboratory. While ethanol does cause size reduction of ova (Frimpong and 180 Henebry, 2012), the same procedure was conducted on all individuals and thus would not affect 181 comparisons.

182 Life history trait variables and measurement 
183

184

185

186

187

188

189

190

191

192

193

194

195

196

197

198

199

200

201

202

203

204

205

A limited number of life history variables were measured on mature females to test

TLHM predictions. We measured mean oocyte diameter to capture the parental investment

(equilibrium) axis, number of mature oocytes to capture the fecundity (periodic) axis, and

smallest size of a mature female to capture the generation time (opportunistic) axis of the TLHM.

Ovaries were extracted and classified according to the external staging method of Heins,

which separates females and oocytes into maturity stages based on oocyte size, coloration, yolk

condition, and physical location in the ovum (Appendix S3) (e.g., Heins and Rabito, 1986; Heins

and Baker, 1993). The diameters of 10 mature, ripening, or ripe oocytes were measured for each

individual using digital microscope photography (Leica MZ 9.5 stereomicroscope, Leica DFC

320 camera; Leica Microsystems, Buffalo Grove, IL, USA) and ImageJ software (NIH,

Washington, D.C.) at 150x magnification. Because most preserved oocytes were not spherical, large and small axes of each oocyte were averaged (Heins and Rabito, 1988). Based on repeated

measurements $(n=5)$ of 10 randomly selected oocytes, measurement variance was low, ranging

from $3.8 \times 10^{-6}$ to $2.7 \times 10^{-4} \mathrm{~mm}$. The number of mature and ripening oocytes was counted to

measure clutch size as an estimate of batch fecundity for each female (Heins and Rabito, 1986;

Heins and Baker, 1993); however, ripe females were not included in counts because they could

have already released some of the clutch before capture (Heins and Baker, 1993). Because

advanced stage oocytes more closely correspond to the size of oocytes released during spawning,

we used only ripening and ripe oocytes to estimate egg size for orangethroat darter and bluntnose

minnow (Heins and Baker, 1988); however, because not all populations of red shiner had

females at these stages, we used mature oocytes in analyses for this species. Females with mature

oocytes were identified and the smallest standard length (SL) was recorded as a measure of

minimum size at maturity (minSLmat), a proxy for generation time (Winemiller and Rose, 1992; 
206 Wootton, 1998). Although interannual variation in egg size and fecundity are important aspects 207 of life history (Wootton, 1998), for the purposes of this study we combined samples from 2013 208 and 2014 within populations when available because our focus was on variation among 209 populations. Trait values were divided by SL to correct for differences in size among populations 210 and correlations between size and other traits, with average individual size-corrected values for 211 fecundity and egg size (individual trait/individual SL) and minSLmat divided by average 212 population SL.

213 Statistical analyses

214 We first evaluated variation in fecundity, egg size, and SL within and among populations 215 using one-way ANOVA (Type III SS) in the R package “car.” Then, for each species, we used 216 multiple linear regression to predict life history traits from flow and latitude (if applicable). We 217 used principal components analysis (PCA) on flow variables to reduce the number of variables 218 for subsequent regression models (Appendix S4), evaluating each principal component (PC) axis 219 based on a broken stick model for interpretability (Jackson 1993) and scree plots. Interpretable 220 PC axes were used in subsequent regression models, which are described below.

221 The multiple linear regression models, combined with multi-model inference based on 222 small sample size Akaike information criteria (AICc) scores, were used to examine relationships 223 between life history traits and flow variables, with each of the three size-corrected life history 224 traits as the dependent variable and flow PCAs (and latitude, if appropriate) as independent 225 variables (ln-transformed). We evaluated all possible combinations of variables in linear models 226 for comparison (including intercept-only model) using the MuMIn package in R. The number of 227 models for each species-trait combination differed based on whether there were two or three flow 228 PCs and whether latitude was included in models (4 models for each life history trait for 
229 orangethroat darter, 8 per trait for red shiner, and 16 per trait for bluntnose minnow). Models 230 were compared using AICc scores, with models within $\Delta 2$ of the lowest AICc considered 231 plausible (Burnham and Anderson, 2002). All size-corrected life history variables were ln232 transformed and models were evaluated to ensure they met assumptions of normality and 233 homogeneity of variance. Traits were scaled to a common axis $(0-1$; with the inverse of 234 minSLmat used to capture the opportunistic axis), and relationships were visualized using 235 ternary plots (SigmaPlot, Systat Software Co., San Jose, CA).

We also conducted PCA for size-corrected, ln-transformed life history traits to evaluate trade-offs in relation to the TLHM. For the life history PCAs, we selected the first two PCs for 238 all species to capture the major variation and trade-offs in traits even if the second axis did not 239 explain more variation than a single variable according to a broken stick model. We examined 240 life history PCAs to determine if trait relations in multivariate space corresponded to the TLHM 241 (Winemiller and Rose, 1992).

\section{RESULTS}

\section{Population-level and species-level trait variability}

$244 \quad$ Fecundity differed significantly among populations for orangethroat darter $\left(\mathrm{F}_{7,194}=31.70\right.$, $245 \quad P<0.001$; raw site means \pm SE: $50.2 \pm 4.3-163.7 \pm 12.8)$, red shiner $\left(\mathrm{F}_{6,61}=2.54, P=0.03\right.$; means: $246221.7 \pm 24.7-475.0 \pm 132.0)$, and bluntnose minnow $\left(\mathrm{F}_{13,84}=2.60, P<0.01 ;\right.$ means: $161 \pm 17.5-$ $247433 \pm 82.5$; Appendix S5). Despite the smaller differences among populations, egg size also 248 differed significantly among populations for orangethroat darter $\left(\mathrm{F}_{7,166}=20.64, P<0.001\right.$; 249 population means: $1.02 \pm 0.008-1.17 \pm 0.008 \mathrm{~mm})$, red shiner $\left(\mathrm{F}_{6,25}=2.74, P=0.03\right.$; means: $250 \quad 0.82 \pm 0.02-0.90 \pm 0.005 \mathrm{~mm})$, and bluntnose minnow $\left(\mathrm{F}_{13,69}=4.94, P<0.001 ;\right.$ means: $0.92 \pm 0.02-$ $251 \quad 1.14 \pm 0.13 \mathrm{~mm}$; Appendix S5). Differences in standard length of mature individuals were 
252 borderline among populations of red shiner $\left(\mathrm{F}_{6,61}=2.15, P=0.06\right.$; population means: $36.7 \pm 1.16-$ $25345.1 \pm 1.4 \mathrm{~mm})$ but did differ for orangethroat darter $\left(\mathrm{F}_{7,194}=9.44, P<0.0001\right.$; means: $32.3 \pm 0.59-$ $25438.7 \pm 0.54 \mathrm{~mm})$ and bluntnose minnow $\left(\mathrm{F}_{13,84}=6.05, P<0.0001\right.$; means: $36.8 \pm 0.90-55.7 \pm 1.05$ $255 \mathrm{~mm}$ ) populations (Appendix S5). Size-corrected fecundity and egg size also differed significantly $256(\mathrm{p}<0.05)$ among populations for all species, except that differences in fecundity among 257 bluntnose minnow populations were borderline $(P=0.06$; Appendix S5).

258 Life history relationships with flow regime

259 Flow PCs explained moderate to substantial portions of variation in some life history 260 traits for all three species examined based on the most informative models $\left(\mathrm{R}^{2}=0.15-0.78\right.$; Tables $2612-4$; only models within $\triangle \mathrm{AICc}=2$ of lowest AICc are discussed). For fecundity in red shiner, the 262 intercept-only model was ranked highest based in AICc; however, a model showing a negative 263 relationship with flow PC2 (negative: HPD, HPC) was ranked second and within $\triangle \mathrm{AICc}=2 \mathrm{of}$ 264 the intercept model (Table 2; Figure 3). The top models for egg size (within $\triangle \mathrm{AICc}=2$ ) showed 265 positive relationships with flow PC1 (positive: BFI, FlowPred; negative: annCV) and latitude, 266 with both models explaining $>70 \%$ of the variation in egg size. For minSLmat, the intercept-only 267 model was ranked best, but a model showing a negative relationship with flow PC1 (positive: 268 BFI, FlowPred; negative: annCV) was ranked second (Table 2; Figure 3).

269 In bluntnose minnow, fecundity was positively related to latitude (best model) and 270 negatively related to flow PC1, higher values of which represented less seasonal flows (lower 271 HPD, higher ConstPred), and flow PC2 (positive: annCV; negative: BFI; Table 3; Figure 4). For 272 egg size, the intercept-only model was ranked best but two models within $\triangle \mathrm{AICc}=2$ showed a 273 positive relationship with flow PC2 (positive: annCV; negative: BFI) and a negative relationship 274 with latitude (Table 3; Figure 4). For minSLmat, the intercept-only model was also ranked as 
275 best, but a model with a positive relationship with flow PC3 (positive: meanQ) was within $276 \Delta \mathrm{AICc}=2$ (Table 3; Figure 4).

277 In orangethroat darter, fecundity was positively related to flow PC2 (positive: HPD; 278 negative: annCV); this model had substantially lower weight than the intercept-only model but 279 was within $\triangle \mathrm{AICc}=2$ of the best-ranked model (Table 4; Figure 5). The intercept-only model 280 also had the best ranking among models for egg size, with the second-ranked model showing a 281 positive relationship with flow PC1 (positive: BFI; negative: HPC, FlowPred; Table 4; Figure 5) 282 that also had substantially lower weight but was within $\triangle \mathrm{AICc}=2$ of the best-ranked model. 283 Among models for minSLmat, the intercept-only model was the best-ranked, but the model 284 showing a positive relationship with flow PC2 (positive:HPD; negative: annCV) had similar 285 weight $(0.45)$ to the intercept-only model $(0.51)$ and was within $\triangle \mathrm{AICc}=2$ of the best-ranked 286 model (Table 4).

287 Life history trait variability and relationships

288 Life history traits along the first two PC axes largely mirrored established life history 289 trade-offs across fish species based on the TLHM (Figure 6; Appendix S4). We interpreted PC1 290 as an equilibrium-to-periodic axis for all species, with the periodic traits of high fecundity and 291 large minSLmat loading at the positive end and the equilibrium trait of large egg size at the 292 negative end of the axis (Figure 6). We interpreted PC2 as an opportunistic to periodic axis for 293 all species, with the opportunistic trait of small minSLmat loading on the negative end of the 294 axis, and the periodic traits of high fecundity or large minSLmat loading on the positive end 295 (Figure 6).

\section{DISCUSSION}


Our results suggest that the trait-based life history trade-offs and strategies of the TLHM

298 may apply at the population level for three common fish species and that some of the predicted

299 effects of flow regime variability and predictability mirror those found at the assemblage level

300 (Mims and Olden, 2012, 2013), suggesting consistent mechanisms. Trade-offs between periodic

301 (large body size, high fecundity) and opportunistic traits (small size at maturity) and between

302 opportunistic and equilibrium traits (large egg size) largely described the life history investment

303 of populations as predicted by the TLHM. While we did select a small number of traits to

304 coincide with the TLHM, there was no a priori reason for these traits to ordinate in a similar

305 fashion.

306 Although the population-level life history traits examined in this study aligned well with

307 the assemblage-based TLHM, the predicted relationships between hydrology and life history

308 traits had variable support. As predicted by the TLHM, populations of bluntnose minnow and

309 orangethroat darter that experience more seasonal (high HPD) and less variable (low CV, HPC)

310 flows had higher fecundity. Also as predicted, sites with greater flow stability (BFI) had

311 populations of red shiner and orangethroat darter with larger eggs. Orangethroat darter

312 populations from low-variability sites and red shiner populations from more stable sites also had

313 larger minSLmat, as predicted. However, counter to TLHM predictions, seasonality and

314 variability measures were correlated in among red shiner sites, leading to a positive relationship

315 between fecundity and HPD/HPC. Higher variability was also associated with larger eggs in

316 bluntnose minnow populations, counter to TLHM predictions. Overall, these relationships

317 suggest that, in many cases, flow regime (or some correlated variable) is associated with life

318 history traits of populations in some ways as predicted by the TLHM and assemblage-level

319 studies (Mims and Olden, 2012). 
Support for TLHM flow-trait associations varied by species, suggesting species-level

321 differences in behavior could influence how organisms experience flow variation. Both minnow

322 species have adhesive eggs, with red shiner often described as crevice spawning but utilizing

323 various substrates and bluntnose minnow attaching eggs to the underside of rocks where they are

324 actively guarded. The orangethroat darter buries eggs in gravel interstices and also does not

325 defend the clutch (Boschung and Mayden, 2004). The different responses of egg size to flow

326 regime in these species (bluntnose minnow: larger eggs with more variable flow; others: larger

327 eggs with more stable flow;) could be a result of different spawning behavior, with more

328 physical protection afforded to bluntnose minnow clutches and eggs of the other two species left

329 at risk of reduced hatching in variable flows (Durham and Wilde, 2006). Larger eggs, which

330 produce larger offspring may be favored under variable flows if mortality at the egg stage is

331 reduced through protection. Flow variables for future trait-environment prediction should be

332 carefully selected as species experience flow variability differently based on life history and

333 behavioral differences (Poff and Ward, 1990; Beachum et al., 2015).

Identifying mechanisms underlying flow-trait relationships is made difficult by trade-offs

335 among traits, and determining which traits could be under selection, or the role of phenotypic

336 plasticity in trait responses, is quite challenging (Wootton and Smith, 2014). For instance, egg

337 size appears inversely correlated with fecundity in our study species, as is commonly the case

338 due to physiological and geometric limits; thus responses of one trait may be the result of

339 selection on another (Wootton and Smith, 2014). The fact that egg size and fecundity generally

340 did not respond to the same flow regime components (except in bluntnose minnow, Table 3)

341 suggests that our patterns may not be merely the result of trade-offs between these traits. Recent

342 studies of fish life history traits have documented substantial local adaptation with a genetic 
343 basis, but particular traits such as egg size may exhibit extreme plasticity (Torres Dowdall et al., 344 2012; Wootton and Smith, 2014).

345 Our estimates of life history traits and flow relationships were inevitably influenced by 346 several factors including small sample sizes and assumptions about measured traits. Small 347 sample sizes are typical for multi-site life history studies of small-bodied fishes over broad 348 geographic regions, and timing sampling effort to spawning at many of sites was difficult, 349 especially for cyprinids. Further, the small size of the streams sampled and the reliance on USGS 350 gages limited the number of available sampling locations. Small sample sizes could influence 351 trait estimates and increase sample variability. Minimum SL at maturity is likely to change with 352 increased sampling because of its dependence on capturing the smallest reproductive individual 353 in a population; however, this trait was correlated with median SL in all species, suggesting that 354 it might be more resilient to sample size effects. The consistency of slopes between the full 355 dataset and the dataset with small samples ( $<4$ individuals) removed in all but one case suggests 356 that our results may be somewhat robust to small sample sizes (Appendix S6). However, related 357 to issues of small sample size, the presence of outliers, particularly in two of the three important 358 models for red shiner (population RCNE in both cases), appeared to drive relationships and 359 should be considered.

360 Although most of the study species lay multiple clutches in a season, we were limited to 361 using batch fecundity due to difficulty in measuring number of clutches per season (Winemiller 362 and Rose, 1992). Batch fecundity is thought to closely correlate with lifetime fecundity (Roff, 363 1992) and is frequently used to characterize fecundity and life history patterns (Winemiller and 364 Rose, 1992); however, the actual relationship for the study species is unknown. If batch 365 fecundity is not strongly correlated with annual or lifetime fecundity in the study species, the 
366 relationships we report may not represent important life history trade-offs or environmental

367 variation. We also used egg size to represent parental investment, and thus an assumption of our

368 study is that parental care behavior remains constant across populations. Increasing parental care

369 behavior may be a more viable evolutionary strategy than increasing fecundity or egg size due to

370 evolutionary constraints of small body size in many stream fishes (Winemiller and Rose, 1992);

371 however, parental care may be less evolutionarily labile than the life history traits in our study

372 (Sternberg and Kennard, 2014). Among the study species, bluntnose minnow exhibits parental

373 care, and this could confound attempts to evaluate investment per progeny in relation to flow

374 regime using only egg size.

375 Our findings combined with those of other studies suggest - whether due to phenotypic

376 plasticity, natural selection, or a combination - intraspecific trait variation in fishes is high

377 (Blanck and Lamouroux, 2006; Frimpong and Angermeier, 2010). Although we were unable to

378 undertake a full assessment of intra- versus inter-specific trait variability, at least one trait per

379 species exhibited substantial variation at the population level that rivaled variability at the family

380 or congeneric level (e.g., compare data in FishTraits, Frimpong and Angermeier, 2009). Such

381 high variability within species could greatly affect community-level trait studies, which normally

382 assign mean trait values to species (Albert et al., 2010; Frimpong and Angermeier, 2010). While

383 the three species studied are known to be widely-distributed and might therefore be expected to

384 exhibit more trait variation than restricted-range species, they are common members of fish

385 assemblages in eastern and central North America. Therefore, while not necessarily suggestive of

386 intraspecific trait variability in fishes as a whole, such variation could have significant bearing on

387 trait models and should be investigated more broadly in fishes. 
The potential for high intraspecific trait variation, coupled with the fact that the TLHM explained life history trait variation at the population level, suggests that efforts to synthesize environmental filtering or habitat template models with demographic life history theory, which is currently lacking, could be valuable (Wootton, 1998). This could be accomplished by linking age- or size-specific mortality or its correlates to key environmental features like flow regime or habitat variability from major template theories like the TLHM or River Habitat Template 394 (Townsend and Hildrew, 1994). Once environmental factors are known to be selective, 395 demographic theory could be used to make new predictions about the effects of the environment 396 on life history traits. With testing and refinement of these predictions, knowledge of how and 397 why individual species respond to environmental conditions and gradients could then improve 398 understanding of community assembly and change (Matthews, 1998).

400 for species and community persistence in the face of continuing habitat destruction and climate 401 change. As functional traits, the life history parameters of the TLHM largely determine 402 individual performance and population viability. For example, there is evidence that larger eggs 403 produce larger offspring (Gale, 1986; Marsh, 1986; Kamler, 2005), which can be stronger and 404 have higher survival under a variety of conditions (Marsh, 1986; Harvey, 1987). Our results 405 suggest that larger eggs and offspring are associated with more stable flow conditions in some 406 species (red shiner, orangethroat darter); thus, increasing flow variability from climate change, as 407 predicted for the Midwestern U.S. (Wuebbles and Hayhoe, 2004), could promote smaller 408 offspring with reduced survival. Trait-environment models that are well-supported at multiple 409 levels of biological organization could help us understand how changing flow or temperature 410 regimes will impact population and community viability and the sustainability of the valuable 
411 ecosystem services that they, and their natural variability, support (Daily, 1997; Luck et al., 412 2003).

\section{ACKNOWLEDGMENTS}

414 The SIU NSF-IGERT Program in Watershed Science and Policy and the Graduate Professional 415 Student Council supported this research. Thanks to J. Adams, K. Baumann, A. Beattie, T.

416 Egdorf, J. Fulgoni, H. Rantala, L. Shoup, B. Zuñiga-Céspedes for field help. Sampling was 417 conducted with permits from IL, IN, KS, MN, MO, NE, and OH and IACUC. K. Gido provided 418 useful discussions that greatly improved the manuscript; and the Freshwater Ecology Lab at SIU 419 provided helpful comments and edits on an earlier draft of the manuscript.

\section{REFERENCES}

421 Ackerly DD, Cornwell WK. 2007. A trait-based approach to community assembly: partitioning 422 423 of species trait values into within- and among-community components. Ecology Letters 10: 135-145 DOI: 10.1111/j.1461-0248.2006.01006.x.

Albert CH, Thuiller W, Yoccoz NG, Douzet R, Aubert S, Lavorel S. 2010. A multi-trait approach reveals the structure and the relative importance of intra- vs. interspecific variability in plant traits. Functional Ecology 24: 1192-1201 DOI: 10.1111/j.13652435.2010.01727.x.

Beachum CE, Michel MJ, Knouft JH. In press. Differential responses of body shape to local and reach scale stream flow in two freshwater fish species. Ecology of Freshwater Fish. DOI: 10.1111/eff.12225.

Blanck A, Lamouroux N. 2006. Large-scale intraspecific variation in life-history traits of European freshwater fish. Journal of Biogeography 34: 862-875 DOI: 10.1111/j.13652699.2006.01654.x. 
434 Boschung HT, Mayden RL. 2004. Fishes Of Alabama. Smithsonian Books Washington, DC.

435 Bossu CM, Beaulieu JM, Ceas PA, Near TJ. 2013. Explicit tests of palaeodrainage connections

436 of southeastern North America and the historical biogeography of Orangethroat Darters

437 (Percidae: Etheostoma: Ceasia). Molecular Ecology 22: 5397-5417 DOI:

$438 \quad 10.1111 / \mathrm{mec} .12485$.

439 Burnham KP, Anderson DR. 2002. Model Selection And Multimodel Inference: A Practical $440 \quad$ Information-Theoretic Approach. Springer: New York, NY.

441 Cattaneo F. 2005a. Does hydrology constrain the structure of fish assemblages in French

442 streams? Local scale analysis. Archiv Fur Hydrobiologie 164: 345-365 DOI:

$443 \quad 10.1127 / 0003-9136 / 2005 / 0164-0345$.

444 Cattaneo F. 2005b. Does hydrology constrain the structure of fish assemblages in French

445 streams? Regional scale analysis. Archiv Fur Hydrobiologie 164: 367-385 DOI:

$446 \quad 10.1127 / 0003-9136 / 2005 / 0164-0367$.

447 Colwell RK. 1974. Predictability, constancy, and contingency of periodic phenomena. Ecology:

$448 \quad 1148-1153$

449 Crutsinger GM, Collins MD, Fordyce JA, Gompert Z, Nice CC, Sanders NJ. 2006. Plant

450 genotypic diversity predicts community structure and governs an ecosystem process.

451 Science 313: 966-968 DOI: 10.1126/science.1128326.

452 Daily G. 1997. Nature’s Services: Societal Dependence On Natural Ecosystems. Island Press:

$453 \quad$ Washington DC.

454 Darwin C. 1861. On The Origin Of Species By Means Of Natural Selection, Or The Preservation $455 \quad$ Of Favoured Races In The Struggle For Life. Murray. 
456 Diniz-Filho JAF, Santos T, Rangel TF, Bini LM. 2012. A comparison of metrics for estimating 457 phylogenetic signal under alternative evolutionary models. Genetics and Molecular 458 Biology 35: 673-679 DOI: 10.1590/S1415-47572012005000053.

459 Durham BW, Wilde GR. 2006. Influence of stream discharge on reproductive success of a $460 \quad$ prairie stream fish assemblage. Transactions of the American Fisheries Society 135: 461 1644-1653 DOI: 10.1577/T05-133.1.

462 Endler JA. 1986. Natural Selection In The Wild. Princeton University Press: Princeton, NJ. 463 Etnier DA, Starnes WC. 1993. The Fishes Of Tennessee. University of Tennessee Press: $464 \quad$ Knoxville, TN.

465 Falcone JA, Carlisle DM, Wolock DM, Meador MR. 2010. GAGES: A stream gage database for 466 evaluating natural and altered flow conditions in the conterminous United States. Ecology 467 91: 621 DOI: 10.1890/09-0889.1.

468 Fleming IA, Gross MR. 1990. Latitudinal clines: a trade-off between egg number and size in $469 \quad$ Pacific salmon. Ecology: 2-11

470 Frimpong EA, Angermeier PL. 2009. Fish Traits: a database of ecological and life-history traits 471 of freshwater fishes of the United States. Fisheries 34:487-495.

472 Frimpong EA, Angermeier PL. 2010. Trait-based approaches in the analysis of stream fish 473 communities. In Community Ecology of Stream Fishes: Concepts, Approaches, and 474 Techniques. American Fisheries Society Symposium 73, Gido KB, Jackson DA (eds). 475 American Fisheries Society: Bethesda, Maryland; 109-136.

476 Frimpong EA, Henebry ML. 2012. Short-term effects of formalin and ethanol fixation and 477 preservation techniques on weight and size of fish eggs. Transactions of the American 478 Fisheries Society 141: 1472-1479 DOI: 10.1080/00028487.2012.694832. 
479 Gale WF. 1986. Indeterminate fecundity and spawning behavior of captive Red Shiners-

480 fractional, crevice spawners. Transactions of the American Fisheries Society 115: 429-

481 437 DOI: 10.1577/1548-8659(1986)115<429:IFASBO>2.0.CO;2.

482 Harvey BC. 1987. Susceptibility of young-of-the-year fishes to downstream displacement by 483 flooding. Transactions of the American Fisheries Society 116: 851-855

484 Heins DC. 1991. Variation in reproductive investment among populations of the longnose shiner, 485 Notropis longirostris, from contrasting environments. Copeia: 736-744

486 Heins DC, Baker JA. 1987. Analysis of factors associated with intraspecific variation in 487 propagule size of a stream-dwelling fish. In Community and Evolutionary Ecology of North American Freshwater Fishes, Matthews WJ, Heins DC (eds).University of Oklahoma Press: Norman, Oklahoma; 223-231.

Heins DC, Baker JA. 1988. Egg sizes in fishes: do mature oocytes accurately demonstrate size statistics of ripe ova? Copeia 1988: 238-240 DOI: 10.2307/1445942.

492 Heins DC, Baker JA. 1993. Clutch production in the darter Etheostoma lynceum and its implications for life-history study. Journal of Fish Biology 42: 819-829 DOI: 10.1111/j.1095-8649.1993.tb00392.x.

495 Heins DC, Rabito FG. 1986. Spawning performance in North American minnows: direct 496 evidence of the occurrence of multiple clutches in the genus Notropis. Journal of Fish Biology 28: 343-357 DOI: 10.1111/j.1095-8649.1986.tb05171.x.

498 Heins DC, Rabito FG. 1988. Reproductive traits in populations of the Weed Shiner, Notropis 499 texanus, from the Gulf Coastal Plain. The Southwestern Naturalist 33: 147-156 DOI: $10.2307 / 3671889$. 
501 Kamler E. 2005. Parent-egg-progeny relationships in teleost fishes: An Energetics Perspective. 502 Reviews in Fish Biology and Fisheries 15: 399-421 DOI: 10.1007/s11160-006-0002-y. 503 Leggett W, Carscadden J. 1978. Latitudinal variation in reproductive characteristics of American 504 Shad (Alosa sapidissima) - evidence for population specific life-history strategies in fish. $505 \quad$ Journal of the Fisheries Research Board of Canada 35: 1469-1478

506 Luck GW, Daily GC, Ehrlich PR. 2003. Population diversity and ecosystem services. Trends in 507 Ecology \& Evolution 18: 331-336 DOI: 10.1016/S0169-5347(03)00100-9.

508 Machado MD, Heins DC, Bart Jr. HL. 2002. Microgeographical variation in ovum size of the 509 blacktail shiner, Cyprinella venusta Girard, in relation to streamflow. Ecology of 510 Freshwater Fish 11: 11-19

511 Marsh E. 1986. Effects of egg size on offspring fitness and maternal fecundity in the 512 orangethroat darter, Etheostoma spectabile (Pisces: Percidae). Copeia: 18-30

513 Matthews WJ. 1998. Patterns In Freshwater Fish Ecology. Chapman \& Hall: New York, NY.

514 McGill BJ, Enquist BJ, Weiher E, Westoby M. 2006. Rebuilding community ecology from 515 functional traits. Trends in Ecology \& Evolution 21: 178-185 DOI:

$516 \quad 10.1016 /$ j.tree.2006.02.002.

517 McManamay RA, Frimpong EA. 2015. Hydrologic filtering of fish life history strategies across 518 the US and implications for streamflow alteration. Ecological Applications 25: 243-263 519 DOI: $10.1890 / 14-0247.1$.

520 McManamay RA, Bevelhimer MS, Frimpong EA. 2014. Associations among hydrologic 521 classifications and fish traits to support environmental flow standards. Ecohydrology: $522 \quad$ 8:460-479 DOI: $10.1002 /$ eco.1517. 
523 Mims MC, Olden JD. 2012. Life history theory predicts fish assemblage response to hydrologic $524 \quad$ regimes. Ecology 93: $35-45$

525 Mims MC, Olden JD. 2013. Fish assemblages respond to altered flow regimes via ecological 526 filtering of life history strategies. Freshwater Biology 58: 50-62 DOI:

$527 \quad 10.1111 /$ fwb. 12037.

528 Morrongiello JR, Bond NR, Crook DA, Wong BBM. 2012. Spatial variation in egg size and egg 529 number reflects trade-offs and bet-hedging in a freshwater fish. Journal of Animal 530 Ecology 81: 806-817

531 Olden JD, Kennard MJ. 2010. Intercontinental comparison of fish life history strategies along a 532 gradient of hydrologic variability. In Community Ecology of Stream Fishes: Concepts, 533 Approaches, and Techniques., Gido KB, Jackson DA (eds). American Fisheries Society: $534 \quad$ Bethesda, Maryland; 83-108.

535 Pflieger WL. 1997. The Fishes Of Missouri. Missouri Department of Conservation: Jefferson $536 \quad$ City, MO.

537 Poff NL, Ward JV. 1990. Physical habitat template of lotic systems: Recovery in the context of 538 historical pattern of spatiotemporal heterogeneity. Environmental Management 14: 629_ $539 \quad 645$ DOI: $10.1007 / B F 02394714$.

540 Poff NLR. 1997. Landscape filters and species traits: towards mechanistic understanding and 541 prediction in stream ecology. Journal of the North American Benthological Society: 391$542 \quad 409$

543 Poff NLR, Allan JD. 1995. Functional organization of stream fish assemblages in relation to $544 \quad$ hydrological variability. Ecology 76: 606-627 
545 Richter BD, Baumgartner JV, Powell J, Braun DP. 1996. A method for assessing hydrologic $546 \quad$ alteration within ecosystems. Conservation Biology 10: 1163-1174

547 Robison HW, Buchanan TM. 1988. Fishes Of Arkansas. University of Arkansas Press: $548 \quad$ Fayetteville, AR.

549 Roff DA. 1992. The Evolution Of Life Histories: Theory And Analysis. Springer: New York, NY. 550 Schönhuth S, Mayden RL. 2010. Phylogenetic relationships in the genus Cyprinella 551 (Actinopterygii: Cyprinidae) based on mitochondrial and nuclear gene sequences. $552 \quad$ Molecular Phylogenetics and Evolution 55: 77-98 DOI: 10.1016/j.ympev.2009.10.030.

553 Smith CL, Powell CR. 1971. The summer fish communities of Brier Creek, Marshall County, $554 \quad$ Oklahoma. American Museum Novitates 2458.

555 Southwood TRE. 1988. Tactics, strategies and templets. Oikos: 3-18

556 Stearns SC. 1992. The Evolution Of Life Histories. Oxford University Press: Oxford, UK.

557 Sternberg D, Kennard MJ. 2014. Phylogenetic effects on functional traits and life history 558 strategies of Australian freshwater fish. Ecography 37: 54-64 DOI: 10.1111/j.16000587.2013.00362.x.

560 Torres Dowdall J, Handelsman CA, Ruell EW, Auer SK, Reznick DN, Ghalambor CK. 2012.

561 Fine-scale local adaptation in life histories along a continuous environmental gradient in 562 Trinidadian guppies. Functional Ecology 26: 616-627 DOI: 10.1111/j.1365$563 \quad 2435.2012 .01980 . x$.

564 Townsend CR, Hildrew AG. 1994. Species traits in relation to a habitat templet for river $565 \quad$ systems. Freshwater Biology 31: 265-275 
566 Verberk WCEP, van Noordwijk CGE, Hildrew AG. 2013. Delivering on a promise: integrating

567 species traits to transform descriptive community ecology into a predictive science.

$568 \quad$ Freshwater Science 32: 531-547 DOI: 10.1899/12-092.1.

569 Vila-Gispert A, Moreno-Amich R, Garcia-Berthou E. 2002. Gradients of life-history variation:

$570 \quad$ an intercontinental comparison of fishes. Reviews in Fish Biology and Fisheries 12: 417-

$571 \quad 427$

572 Winemiller KO, Rose KA. 1992. Patterns of life-history diversification in North American

573 fishes: implications for population regulation. Canadian Journal of Fisheries and Aquatic

$574 \quad$ Science 49: 2196-2218

575 Wootton RJ. 1998. Ecology Of Teleost Fishes. Springer: New York, NY.

576 Wootton RJ, Smith C. 2014. Reproductive Biology Of Teleost Fishes. Wiley-Blackwell.

577 Wuebbles DJ, Hayhoe K. 2004. Climate Change Projections for the United States Midwest.

$578 \quad$ Mitigation and Adaptation Strategies for Global Change 9: 335-363 DOI:

579 10.1023/B:MITI.0000038843.73424.de.

580

581

582

583

584

585

586

587

588

589 
590 Table 1. Hydrologic metrics and predicted impacts of their increase on life history strategy and

591 traits used in this study (modified from Mims \& Olden 2012). Letters after metrics refer to flow

592 regime component measured by metric: $\mathrm{V}=$ variability, $\mathrm{P}=$ predictability, $\mathrm{S}=$ seasonality. $+=$

593 predict positive relationship between flow variable and traits; - = predict negative relationship

594 between flow variable and traits; $0=$ predict no relationship between flow variable and traits.

\begin{tabular}{|c|c|c|c|c|c|}
\hline \multirow[b]{2}{*}{ Hydrologic parameter } & \multirow[b]{2}{*}{ Abbreviation } & \multirow[b]{2}{*}{ Description } & \multicolumn{3}{|c|}{ Predicted relationship w/ life history strategy } \\
\hline & & & $\begin{array}{l}\text { Opportunistic } \\
\text { (small size at } \\
\text { maturity) }\end{array}$ & $\begin{array}{l}\text { Periodic } \\
\text { (high } \\
\text { fecundity) }\end{array}$ & $\begin{array}{l}\text { Equilibrium } \\
\text { (large egg size) }\end{array}$ \\
\hline $\begin{array}{l}\text { Annual coefficient of } \\
\text { variation }(V)\end{array}$ & AnnCV & $\begin{array}{l}\text { Standard deviation of all } \\
\text { daily flow values divided } \\
\text { by mean annual flow }\end{array}$ & + & - & - \\
\hline High pulse count (V) & HPC & $\begin{array}{l}\text { Number of flows }>75^{\text {th }} \\
\text { percentile each year }\end{array}$ & + & - & - \\
\hline Base flow index (P) & $\mathrm{BFI}$ & $\begin{array}{l}\text { 7-day minimum } \\
\text { flow/mean flow for year }\end{array}$ & - & 0 & + \\
\hline Flow predictability $(\mathrm{P})$ & FlowPred & $\begin{array}{l}\text { Constancy (measure of } \\
\text { temporal invariance) + } \\
\text { contingency (measure of } \\
\text { periodicity) }\end{array}$ & - & + & + \\
\hline $\begin{array}{l}\text { Constancy/predictability } \\
\text { (S) }\end{array}$ & Const/Pred & $\begin{array}{l}\text { Constancy/(constancy + } \\
\text { contingency) }\end{array}$ & 0 & - & + \\
\hline High pulse duration (S) & HPD & $\begin{array}{l}\text { Median duration of flows } \\
>75^{\text {th }} \text { percentile }\end{array}$ & - & + & 0 \\
\hline Mean discharge $^{1}$ & MeanQ & $\begin{array}{l}\text { Average of daily flows } \\
\text { over study period }\end{array}$ & $-?$ & + & $+/-$ \\
\hline
\end{tabular}

${ }^{1}$ Predictions for meanQ are based on other literature sources (Heins and Baker, 1987; Heins and Rabito, 1988; Heins, 1991; Machado et al., 2002; Cattaneo, 2005a, 2005b; Morrongiello et al., 2012). Prediction for Opportunistic strategy based on correlation with periodic traits (larger size and size at maturity). 
595 Table 2. Regression model selection results for fecundity, egg size, and minimum SL at maturity (minSLmat) for all species. Bold

596 models indicate those within $\triangle \mathrm{AICc}=2$ of lowest $\mathrm{AICc}$. For red shiner and bluntnose minnow, only four best-ranked models shown for

597 each trait of a possible eight and 16 models, respectively.

\begin{tabular}{|c|c|c|c|c|c|c|c|c|c|c|c|}
\hline \multirow[b]{2}{*}{ Model } & \multirow[b]{2}{*}{$\mathbf{R}^{2}$} & \multirow[b]{2}{*}{ df } & \multirow[b]{2}{*}{ logLlk } & \multirow[b]{2}{*}{ AICc } & \multirow[b]{2}{*}{$\triangle \mathrm{AICc}$} & \multirow[b]{2}{*}{ weight } & \multicolumn{5}{|c|}{ Model Coefficients } \\
\hline & & & & & & & Intercept & Latitude & flowPC1 & flowPC2 & flowPC3 \\
\hline Red Shiner & & & $\sqrt{2}$ & & & & & & & & \\
\hline Fecundity (intercept) & 0.00 & 2 & -0.063 & 7.1 & 0.00 & 0.62 & 0 & & & & - \\
\hline Fecundity FlowPC2 & 0.56 & 3 & 2.795 & 8.4 & 1.28 & 0.327 & 0 & & & -0.747 & - \\
\hline Fecundity FlowPC1 & 0.13 & 3 & 0.413 & 13.2 & 6.05 & 0.030 & 0 & & -0.357 & & - \\
\hline Fecundity Latitude & 0.01 & 3 & -0.043 & 14.1 & 6.96 & 0.019 & 0 & -0.076 & & & - \\
\hline Egg size FlowPC1 & 0.78 & 3 & 11.119 & -8.2 & 0.00 & 0.638 & 0 & & 0.885 & & - \\
\hline Egg size Latitude & 0.72 & 3 & 10.209 & -6.4 & 1.82 & 0.257 & 0 & 0.848 & & & - \\
\hline Egg size (intercept) & 0.00 & 2 & 5.763 & -4.5 & 3.71 & 0.100 & 0 & & & & - \\
\hline Egg size FlowPC2 & 0.00 & 3 & 5.772 & 2.5 & 10.70 & 0.003 & 0 & & & 0.051 & - \\
\hline MinSLmat (intercept) & 0.00 & 2 & 3.724 & -0.4 & 0.00 & 0.476 & 0 & & & & - \\
\hline MinSLmat FlowPC1 & 0.60 & 3 & 6.950 & 0.1 & 0.55 & 0.362 & 0 & & -0.776 & & - \\
\hline MinSLmat Latitude & 0.49 & 3 & 6.048 & 1.9 & 2.35 & 0.147 & 0 & -0.697 & & & - \\
\hline MinSLmat FlowPC2 & 0.02 & 3 & 3.778 & 6.4 & 6.89 & 0.015 & 0 & & & -0.124 & - \\
\hline \multicolumn{12}{|l|}{ Bluntnose Minnow } \\
\hline Fecundity Latitude & 0.43 & 3 & -0.428 & 9.3 & 0.00 & 0.325 & 0 & 0.657 & & & \\
\hline Fecundity FlowPC1+2 & 0.54 & 4 & 1.111 & 10.2 & 0.97 & 0.200 & 0 & & -0.422 & -0.604 & \\
\hline Fecundity FlowPC2 & 0.37 & 3 & -1.196 & 10.8 & 1.54 & 0.150 & 0 & & & -0.604 & \\
\hline
\end{tabular}




\begin{tabular}{|c|c|c|c|c|c|c|c|c|c|c|c|}
\hline Fecundity Lat+FlowPC2 & 0.49 & 4 & 0.270 & 11.9 & 2.65 & 0.086 & 0 & 0.457 & & -0.306 & \\
\hline Egg size (intercept) & 0.00 & 2 & 14.540 & -24.0 & 0.00 & 0.283 & 0 & & & & \\
\hline Egg size FlowPC2 & 0.17 & 3 & 15.823 & -23.2 & 0.74 & 0.195 & 0 & & & 0.409 & \\
\hline Egg size Latitude & 0.15 & 3 & 15.688 & -23.0 & 1.01 & 0.171 & 0 & -0.389 & & & \\
\hline Egg size FlowPC1 & 0.09 & 3 & 15.173 & -21.9 & 2.04 & 0.102 & 0 & & 0.294 & & \\
\hline MinSLmat (intercept) & 0.00 & 2 & 17.167 & -29.2 & 0.00 & 0.300 & 0 & & & & \\
\hline MinSLmat FlowPC3 & 0.16 & 3 & 18.355 & -28.3 & 0.93 & 0.188 & 0 & & & & 0.395 \\
\hline MinSLmat FlowPC2 & 0.07 & 3 & 17.654 & -26.9 & 2.34 & 0.093 & 0 & & & -0.259 & \\
\hline MinSLmat FlowPC1 & 0.06 & 3 & 17.620 & -26.8 & 2.40 & 0.090 & 0 & & -0.250 & & \\
\hline \multicolumn{12}{|l|}{ Orangethroat Darter } \\
\hline Fecundity (intercept) & 0.00 & 2 & -2.519 & 11.4 & 0.00 & 0.681 & 0 & - & & & - \\
\hline Fecundity FlowPC2 & 0.38 & 3 & -0.625 & 13.3 & 1.81 & 0.275 & 0 & - & & 0.614 & - \\
\hline Fecundity FlowPC1 & 0.00 & 3 & -2.514 & 17.0 & 5.59 & 0.042 & 0 & - & 0.033 & & - \\
\hline Fecundity FlowPC1+2 & 0.38 & 4 & -0.618 & 22.6 & 11.13 & 0.003 & 0 & - & 0.033 & 0.614 & - \\
\hline Egg size (intercept) & 0.00 & 2 & 10.650 & -14.9 & 0.00 & 0.661 & 0 & - & & & - \\
\hline Egg size FlowPC1 & 0.37 & 3 & 12.513 & -13.0 & 1.87 & 0.259 & 0 & - & 0.610 & & - \\
\hline Egg size FlowPC2 & 0.14 & 3 & 11.241 & -10.5 & 4.42 & 0.073 & 0 & - & & -0.371 & - \\
\hline Egg size FlowPC1+2 & 0.51 & 4 & 13.501 & -5.7 & 9.23 & 0.007 & 0 & - & 0.610 & -0.371 & - \\
\hline MinSLmat (intercept) & 0.00 & 2 & -13.836 & -21.3 & 0.00 & 0.511 & 0 & - & & & - \\
\hline MinSLmat FlowPC2 & 0.49 & 3 & 16.510 & -21.0 & 0.25 & 0.450 & 0 & - & & 0.698 & - \\
\hline MinSLmat FlowPC1 & 0.02 & 3 & 13.916 & -15.8 & 5.44 & 0.034 & 0 & - & 0.141 & & - \\
\hline MinSLmat FlowPC1+2 & 0.51 & 4 & 16.667 & -12.0 & 9.27 & 0.005 & 0 & - & 0.141 & 0.698 & - \\
\hline
\end{tabular}




\section{Figure Legends}

Figure 1. The trilateral life history framework of Winemiller and Rose (1992). Modified from Winemiller (2005), and Mims and Olden (2012).

Figure 2. Map of study sites where mature (mature, ripening, or ripe) specimens of target species were found. For site codes and information, see Appendix S1.

Figure 3. Population life history strategies and flow-trait relationships for red shiner. (a) Ternary plot illustrating trade-offs in traits among populations. Axes scaled between 0 and 1 for the three traits (bottom axis: fecundity; right axis: egg size; left axis: inverse(minSLmat)). Solid circles represent study sites (see Appendix S1). (b) Scatterplots of flow PC-trait relationships. Asterisk indicates important relationship from multiple regression results (Table 2). Higher values of flow PC1 (lower CV), in left panels, were associated with larger eggs and smaller size at maturity. Higher values of flow PC2 (lower HPC, HPD, higher CV), on right panels, were associated with lower fecundity. Illustration of male red shiner copyright and used with permission of Joseph R. Tomelleri.

Figure 4. Population life history strategies and flow-trait relationships for bluntnose minnow. (a) Ternary plot illustrating trade-offs in traits among populations. Axes scaled between 0 and 1 for the three traits (bottom axis: fecundity; right axis: egg size; left axis: inverse(minSLmat)). Solid circles represent study sites (see Appendix S1). (b) Scatterplots of flow PC-trait relationships. Asterisk indicates important relationship from multiple regression results (Table 2). Higher values of flow PC1 (lower HPD, higher ConstPred), in left panels, were associated with lower 
fecundity. Higher values of flow PC2 (higher CV, HPC; lower BFI), in middle panels, were associated with lower fecundity and larger egg size. Higher values of flow PC3 (higher meanQ), right panels, were associated with larger size at maturity. Illustration of male bluntnose minnow copyright and used with permission of Joseph R. Tomelleri.

Figure 5. Population life history strategies and flow-trait relationships for orangethroat darter. (a) Ternary plot illustrating trade-offs in traits among populations. Axes scaled between 0 and 1 for the three traits (bottom axis: fecundity; right axis: egg size; left axis: inverse(minSLmat)). Solid circles represent study sites (see Appendix S1). (b) Scatterplots of flow PC-trait relationships. Asterisk indicates important relationship from multiple regression results (Table 2). Higher values of flow PC1 (higher BFI, lower HPC) were associated with larger eggs. Higher values of flow PC2 (higher HPD, lower CV) were associated with higher fecundity and larger size at maturity. Illustration of male orangethroat darter (E. spectabile pulchellum) copyright and used with permission of Joseph R. Tomelleri.

Figure 6. Principal component plots for life history traits for (left to right) red shiner, bluntnose minnow, and orangethroat darter. We interpreted PC1 as an equilibrium (negative) to periodic (positive) axis for all species. We interpreted PC2 as an opportunistic (around zero) to periodic (positive or negative) axis for all species. Red text associated with arrows identifies trait vectors (ln-transformed, size-corrected traits). Uppercase black text identifies site scores (see Appendix S1). Fish illustrations copyright and used with permission of Joseph R. Tomelleri. 


\section{Supplementary Material}

Appendix S1. Sample and gage locations and collecting information

Appendix S2. Additional environmental and other data for study sites and evaluation for inclusion in final model sets

Appendix S3. Ovary and oocyte stages and descriptions

Appendix S4. Principal components results for flow and life history trait variable reduction

Appendix S5. Data on life history trait variability among populations

Appendix S6. Comparison of results from full datasets with results after small samples removed 


\section{Population-level responses of life history traits to flow regime in three common stream fish species}

Micah G. Bennett ${ }^{1}$, Matt R. Whiles ${ }^{1}$, and Gregory W. Whitledge ${ }^{1,2}$

Electronic supporting material

${ }^{1}$ Department of Zoology and Center for Ecology, Southern Illinois University, 1125 Lincoln Drive (Mail Code 6501), Carbondale, Illinois 62901

${ }^{2}$ Center for Fisheries, Aquaculture, and Aquatic Sciences, Southern Illinois University, 1125 Lincoln Drive (Mail Code 6511), Carbondale, Illinois 62901

*corresponding author

email: micahgbennett@yahoo.com

phone: $618-453-4125$ 
The following Supporting Information is available for this article:

Appendix S1. Sample and gage locations and collecting information

Appendix S2. Additional environmental and other data for study sites and evaluation for inclusion in final model sets

Appendix S3. Ovary and oocyte stages and descriptions

Appendix S4. Principal components results for flow and life history trait variable reduction

Appendix S5. Data on life history trait variability among populations

Appendix S6. Comparison of results from full datasets with results after small samples removed 
Appendix S1. Sample and gage location selection and collecting information.

To limit the influence of anthropogenic flow modification, potential study reaches were selected based on proximity to "reference" USGS stream gages from the GAGES (Gages for Evaluating Stream Flow) database (Falcone et al., 2010). This database contains USGS stream gages with discharge data from 1950-2007 and determines "reference" gage designations based on anthropogenic modification of stream flow in the gaged watersheds, including human population and urban/housing density and presence of dams and channelization (Falcone et al., 2010). Gages within the Central Lowlands physiographic province were further selected to limit variability based on ecoregion while still maintaining a large number of potential gages from which to select.

Reference gages were narrowed by selecting those with comparable temporal coverage ( $\geq 15$ years of flow data prior to $2013 ;>40 \%$ overlap in period of flow record) and excluding gages with >10 days of missing data per year (Kennard et al., 2010; Mims and Olden, 2012). Finally, the partitioning around medioids (PAM) procedure ("pam" command) in the package “cluster" in R (R Core Team, 2012) was used to group gages based on similarity in drainage size. PAM is a non-hierarchical clustering method that searches for representative medioids (point nearest a multivariate centroid) among observations and assigns each observation to one of these medioids, forming clusters (Borcard et al., 2011). Three groupings were best as judged by average silhouette width (degree of membership of an observation to a cluster) (Borcard et al., 2011), and the largest group was selected $(n=31)$. Particular gage sites were then selected which spanned the range of variation in the hydrologic metrics and were likely to contain the target species based on information from fish collections (FishNet2, Illinois Natural History Survey, U. of Kansas, Ohio State U., Indiana Dept. of Environmental Management) and the Global 
Biodiversity Information Facility (www.gbif.org). Final sampling locations containing the target species were all within the Mississippi-Ohio River watershed (Figure 2; Appendix S1). Of the sites sampled, we obtained reproductive individuals from seven populations of red shiner, eight populations of orangethroat darter, and 14 populations of bluntnose minnow (Appendix S1).

References

Borcard D, Gillet F, Legendre P. 2011. Numerical Ecology With R. Springer: New York.

Falcone JA, Carlisle DM, Wolock DM, Meador MR. 2010. GAGES: A stream gage database for evaluating natural and altered flow conditions in the conterminous United States. Ecology 91: 621 DOI: 10.1890/09-0889.1.

Kennard MJ, Mackay SJ, Pusey BJ, Olden JD, Marsh N. 2010. Quantifying uncertainty in estimation of hydrologic metrics for ecohydrological studies. River Research and Applications 26: $137-156$

Mims MC, Olden JD. 2012. Life history theory predicts fish assemblage response to hydrologic regimes. Ecology 93: $35-45$

R Core Team. 2012. R: A Language And Environment For Statistical Computing. R Foundation for Statistical Computing: Vienna, Austria. 
Table S1. Species columns contain number of individuals for fecundity and egg size estimates, respectively. Mature and ripening oocytes were combined to estimate fecundity, but only ripening and ripe oocytes were used to estimate egg size when available (except for Red Shiner; see text and Appendix S3).

\begin{tabular}{|c|c|c|c|c|c|c|c|c|c|c|}
\hline $\begin{array}{l}\text { Gage } \\
\text { No }_{1}\end{array}$ & Code & Site Name & Drainage & Lat & Long & $\begin{array}{l}\text { Flow } \\
\text { Years }\end{array}$ & $\begin{array}{l}\text { Red Shiner } \\
\text { (fecundity; } \\
\text { egg size) }\end{array}$ & $\begin{array}{l}\text { Bluntnose } \\
\text { Minnow } \\
\text { (fecundity; } \\
\text { egg size) }\end{array}$ & $\begin{array}{l}\text { Orangethroat } \\
\text { Darter } \\
\text { (fecundity; egg } \\
\text { size) }\end{array}$ & $\begin{array}{l}\text { Sample } \\
\text { Years }\end{array}$ \\
\hline 5556500 & BBIL & $\begin{array}{l}\text { Big Bureau Cr., } \\
\text { Princeton, IL }\end{array}$ & Illinois R. & 41.37 & -89.50 & $\begin{array}{l}1938- \\
2012\end{array}$ & $0 ; 0$ & $15 ; 15$ & $18 ; 29$ & $\begin{array}{l}2013 \\
2014\end{array}$ \\
\hline 3340800 & BRIN & $\begin{array}{l}\text { Big Raccoon Cr., } \\
\text { Fincastle, IN }\end{array}$ & Wabash R. & 39.81 & -86.95 & $\begin{array}{l}1958- \\
2012\end{array}$ & - & $10 ; 9$ & - & 2014 \\
\hline 3364500 & CCIN & Clifty Cr., Hartsville, IN & E. Fk. White R. & 39.27 & -85.70 & $\begin{array}{l}1949- \\
2012\end{array}$ & - & $1 ; 2$ & - & 2014 \\
\hline 7180500 & CCKS & $\begin{array}{l}\text { Cedar Cr., Cedar Point, } \\
\text { KS }\end{array}$ & $\begin{array}{l}\text { Cottonwood/ } \\
\text { upper Neosho R. }\end{array}$ & 38.20 & -96.82 & $\begin{array}{l}1939- \\
2012\end{array}$ & $6 ; 5$ & $8 ; 6$ & $38 ; 17$ & $\begin{array}{l}2013 \\
2014\end{array}$ \\
\hline 5503800 & CCMO & Crooked Cr., Paris, MO & $\begin{array}{l}\text { Salt R. (upper } \\
\text { Mississippi R.) }\end{array}$ & 39.58 & -91.99 & $\begin{array}{l}1980- \\
2012\end{array}$ & $2 ; 2$ & $17 ; 13$ & $43 ; 13$ & $\begin{array}{l}2013 \\
2014\end{array}$ \\
\hline 5444000 & ECIL & Elkhorn Cr., Penrose, IL & Rock R. & 41.90 & -89.70 & $\begin{array}{l}1940- \\
2012\end{array}$ & - & $14 ; 11$ & - & $\begin{array}{l}2013 \\
2014\end{array}$ \\
\hline 7184000 & LCKS & $\begin{array}{l}\text { Lightning Cr., McCune, } \\
\text { KS }\end{array}$ & Neosho R. & 37.28 & -95.03 & $\begin{array}{l}1960- \\
2012\end{array}$ & $2 ; 2$ & $2 ; 2$ & $16 ; 20$ & 2014 \\
\hline 5317200 & LCMN & $\begin{array}{l}\text { Little Cottonwood R., } \\
\text { Courtland, MN }\end{array}$ & Minnesota R. & 44.25 & -94.34 & $\begin{array}{l}1974- \\
2009\end{array}$ & - & $2 ; 1$ & - & 2013 \\
\hline 5507600 & LCMO & Lick Cr., Perry, MO & $\begin{array}{l}\text { Salt R. (upper } \\
\text { Mississippi R.) }\end{array}$ & 39.43 & -91.68 & $\begin{array}{l}1980- \\
2012\end{array}$ & $0 ; 0$ & $2 ; 1$ & $20 ; 40$ & 2014 \\
\hline 6910800 & MdCKS & $\begin{array}{l}\text { Marais des Cygnes R., } \\
\text { Reading, KS }\end{array}$ & $\begin{array}{l}\text { Marais des } \\
\text { Cygnes/ Osage R. }\end{array}$ & 38.57 & -95.96 & $\begin{array}{l}1970- \\
2012\end{array}$ & $20 ; 13$ & $9 ; 7$ & $26 ; 25$ & $\begin{array}{l}2013 \\
2014\end{array}$ \\
\hline 7167500 & OCKS & Otter Cr., Climax, KS & Fall/Verdigris R. & 37.71 & -96.22 & 1947- & $2 ; 2$ & $6 ; 6$ & $21 ; 11$ & 2014 \\
\hline
\end{tabular}




\begin{tabular}{|c|c|c|c|c|c|c|c|c|c|c|}
\hline \multirow{2}{*}{3327520} & \multirow[b]{2}{*}{$\mathrm{PCIN}$} & \multirow[b]{2}{*}{ Pipe Cr., Bunker Hill, IN } & \multirow[b]{2}{*}{ Wabash R. } & \multicolumn{4}{|c|}{2012} & \multirow[b]{2}{*}{$1 ; 1$} & \multirow[b]{2}{*}{-} & \multirow[b]{2}{*}{2013} \\
\hline & & & & 40.67 & -86.10 & $\begin{array}{l}1969- \\
2003\end{array}$ & - & & & \\
\hline 6803530 & RCNE & Rock Cr., Ceresco, NE & Salt Cr./ Platte R. & 41.02 & -96.54 & $\begin{array}{l}1941- \\
2012\end{array}$ & $24 ; 5$ & - & - & $\begin{array}{l}2013 \\
2014\end{array}$ \\
\hline 6889160 & SCKS & Soldier Cr., Circleville, KS & Kansas R. & 39.46 & -95.95 & $\begin{array}{l}1965- \\
2000\end{array}$ & $12 ; 4$ & $9 ; 7$ & $20 ; 18$ & 2014 \\
\hline 3272700 & $\mathrm{SCOH}$ & $\begin{array}{l}\text { Sevenmile Cr., Camden, } \\
\mathrm{OH}\end{array}$ & Great Miami R. & 39.63 & -84.64 & $\begin{array}{l}1971- \\
2000\end{array}$ & - & $2 ; 2$ & - & 2013 \\
\hline
\end{tabular}

${ }^{1}$ U.S. Geological Survey, www.waterdata.usgs.gov 


\begin{abstract}
Appendix S2. Additional environmental and other data for study sites and evaluation for inclusion in final model sets.
\end{abstract}

Many environmental factors that can influence life history such as growing season, temperature, and climate patterns are correlated with latitude, and several studies have found significant latitudinal clines in life history traits (Leggett and Carscadden, 1978; Fleming and Gross, 1990; Johnston and Leggett, 2002). Latitude was calculated for each site from Google Earth (Google, Inc., Mountain View, CA) and included in final models for Bluntnose Minnow and Red Shiner based on significant regressions for some traits $(\mathrm{p}<0.05)$.

Recent molecular data suggest that our sampling sites for Orangethroat Darter include three distinct phylogenetic clades reflective of ancient drainage configurations, glacial refugia, and dispersal events (Bossu et al., 2013): a western clade (including sites CCKS, LCKS, OCKS, SCKS) that included Etheostoma spectabile pulchellum and E. s. squamosum, which separated from populations east of Kansas approximately 4.5 Ma during the Pliocene (Bossu et al. 2013); two sister clades from the Osage and Marais des Cygnes rivers (including site MdCKS) and lower portions of middle Mississippi River and tributaries; and a clade including upper Mississippi River tributaries (including the Illinois River and presumably site BBIL in the Illinois drainage and presumably sites CCMO and LCMO in the Salt River, but this drainage was not sampled). Because life history traits could be influenced more by evolutionary history than local environmental conditions (Harvey and Pagel, 1991; Stearns, 1992), we evaluated the effect of genetic divergence on life history traits using published data on the cytochrome b (cyt b) gene (Bossu et al., 2013). We obtained 90 cyt b sequences used by Bossu et al. (2013) from GenBank (http://www.ncbi.nlm.nih.gov/genbank/) representing all available cyt b sequences from the clades listed above. Similar to Olden and Kennard (2010), we conducted a Mantel test (phytools 
package in R with 999 permutations) between raw genetic and life history distances (lntransformed, size-corrected values of fecundity, minSLmat, and egg diameter) based on Euclidean distances calculated in the vegan package in R. Based on this test, life history differences were not significantly related to genetic divergence among populations $\left(R^{2}=0.01\right.$, $\mathrm{P}=0.49)$.

Detailed phylogeographic information was not available for the other study species; however, because our study area encompasses mostly formerly-glaciated streams, we used pairwise stream distances as a potential corollary of genetic divergence due to dispersal limitation and isolation-by-distance. This is a feature of phylogeographic patterns in portions of the range of some minnow species (e.g., Echelle et al. 2014) but ignores the likelihood of dispersal from several glacial refugia (e.g., Berendzen et al. 2003; Berendzen et al. 2008) and resulting patterns that would contradict simple isolation-by-distance. We calculated pairwise stream distances $(\mathrm{km})$ among all populations of Red Shiner and Bluntnose Minnow in ArcMap 10.2 (Network Analyst Tool) and used them in Mantel tests with trait distances among all populations calculated as with Orangethroat Darter. For Red Shiner $\left(\mathrm{R}^{2}=0.001, \mathrm{P}=0.80\right)$ and Bluntnose Minnow $\left(\mathrm{R}^{2}=0.005, \mathrm{P}=0.55\right)$, stream distances did not significantly explain differences in life history traits.

\section{References}

Berendzen PB, Gamble T, Simons AM. 2008. Phylogeography of the bigeye chub Hybopsis amblops (Teleostei: Cypriniformes): early Pleistocene diversification and post-glacial range expansion. Journal of Fish Biology 73: 2021-2039

Berendzen PB, Simons AM, Wood RM. 2003. Phylogeography of the northern hogsucker, Hypentelium nigricans (Teleostei: Cypriniformes): genetic evidence for the existence of the ancient Teays River. Journal of Biogeography 30: 1139-1152 
Bossu CM, Beaulieu JM, Ceas PA, Near TJ. 2013. Explicit tests of palaeodrainage connections of southeastern North America and the historical biogeography of Orangethroat Darters (Percidae: Etheostoma: Ceasia). Molecular Ecology 22: 5397-5417 DOI: 10.1111/mec.12485.

Echelle AA, Schwemm MR, Lang NJ, Nagle BC, Simons AM, Unmack PJ, Fisher WL, Hoagstrom CW. 2014. Molecular systematics and historical biogeography of the Nocomis biguttatus species group (Teleostei: Cyprinidae): nuclear and mitochondrial introgression and a cryptic Ozark species. Molecular Phylogenetics and Evolution 81: 109-119 DOI:

10.1016/j.ympev.2014.09.011.

Fleming IA, Gross MR. 1990. Latitudinal clines: a trade-off between egg number and size in Pacific salmon. Ecology: 2-11

Harvey PH, Pagel MD. 1991. The Comparative Method In Evolutionary Biology. Oxford university press Oxford.

Johnston TA, Leggett WC. 2002. Maternal and environmental gradients in the egg size of an iteroparous fish. Ecology 83: 1777-1791

Leggett W, Carscadden J. 1978. Latitudinal variation in reproductive characteristics of American Shad (Alosa sapidissima) - evidence for population specific life-history strategies in fish. Journal of the Fisheries Research Board of Canada 35: 1469-1478

Olden JD, Kennard MJ. 2010. Intercontinental comparison of fish life history strategies along a gradient of hydrologic variability. In Community Ecology of Stream Fishes: Concepts, Approaches, and Techniques., Gido KB, Jackson DA (eds).American Fisheries Society: Bethesda, Maryland; 83108.

Stearns SC. 1992. The Evolution Of Life Histories. Oxford University Press: Oxford, UK. 
Appendix S3. Ovary and oocyte stages and descriptions ${ }^{\mathrm{a}}$.

\begin{tabular}{|c|c|}
\hline Stage & Description \\
\hline Latent (LA) & $\begin{array}{l}\text { Ovaries transparent-translucent and thin; } \\
\text { maturing oocytes without visible yolk or with } \\
\text { nucleus still visible }\end{array}$ \\
\hline Early Maturing (EM) & $\begin{array}{l}\text { Ovaries translucent to opaque and small- } \\
\text { moderate sized; maturing oocytes are small- } \\
\text { moderate, translucent to opaque, and with } \\
\text { nucleus obscured by yolk }\end{array}$ \\
\hline Late Maturing (LM) & $\begin{array}{l}\text { Ovaries white to cream and small to greatly } \\
\text { enlarged; maturing oocytes are moderate to } \\
\text { large and white-cream or yellow }\end{array}$ \\
\hline Mature (MA) & $\begin{array}{l}\text { Ovaries cream to yellow and moderately to } \\
\text { very enlarged; two distinct groups of oocytes } \\
\text { present including a group of small oocytes } \\
\text { (translucent to opaque) and a group of larger } \\
\text { oocytes that are opaque and cream to yellow } \\
\text { but without vitelline membrane (membrane } \\
\text { surrounding yolk) separated from yolk }\end{array}$ \\
\hline Ripening (MR) & $\begin{array}{l}\text { Ovaries cream to yellow and moderately to } \\
\text { very enlarged; two distinct groups of oocytes } \\
\text { present including a group of small oocytes and } \\
\text { a group of larger oocytes that are translucent } \\
\text { or transparent with the vitelline membrane } \\
\text { obviously separated from yolk }\end{array}$ \\
\hline Ripe (RE) & $\begin{array}{l}\text { Ovaries cream to yellow and moderately sized } \\
\text { to greatly enlarged; two groups of relatively } \\
\text { large oocytes present including a group of } \\
\text { white-cream moderate to large maturing } \\
\text { oocytes and a group of translucent to } \\
\text { transparent ripe oocytes positioned toward } \\
\text { the ovipositor with the vitelline membrane } \\
\text { separated from yolk }\end{array}$ \\
\hline
\end{tabular}

a (Heins and Rabito 1986; Heins and Baker 1993; Ross 2013)

\section{References}


Heins DC, Baker JA. 1993. Reproductive biology of the brighteye darter, Etheostoma lynceum (Teleostei: Percidae), from the Homochitto River, Mississippi. Ichthyological Exploration of Freshwaters 4: $11-20$

Heins DC, Rabito FG. 1986. Spawning performance in North American minnows: direct evidence of the occurrence of multiple clutches in the genus Notropis. Journal of Fish Biology 28: 343-357 DOI: 10.1111/j.1095-8649.1986.tb05171.x.

Ross S. 2013. Ecology Of North American Freshwater Fishes. University of California Press: Oakland, CA. 
Appendix S4. Principal components results for flow and life history trait variable reduction.

\section{Flow variable reduction}

Many of the hydrologic variables were highly correlated based on PCA (Table 1; Figures 1-3).

Flow variation across orangethroat darter populations was best explained by the first two PC axes ( $75 \%$ of the variation). We interpreted the first PC as a contrast between flow variability (high negative loadings of HPC) and predictability (high positive loadings of BFI); however, the other measure of predictability (FlowPred) also loaded strongly positively. We interpreted the second PC as a contrast between variability (high negative loadings of annCV) and both discharge and seasonality (high positive loadings of meanQ and HPD, negative loadings for ConstPred). Variables across red shiner populations were best explained by the first two PC axes (84\% of variation; Appendix S4). We interpreted the first axis as a contrast between variability (high negative loadings of annCV) and predictability (high positive loadings of BFI and FlowPred). We interpreted the second axis as contrasting variability and seasonality (high negative loadings of HPC and HPD) with predictability (less negative or near zero loadings of BFI and FlowPred). Variables across bluntnose minnow populations were best explained by the first three PC axes (77\% of variation; Table 1). We interpreted the first axis as contrasting seasonality from other metrics (high negative loadings of HPD, positive loadings for ConstPred); the second axis as contrasting predictability (high negative loadings of BFI and FlowPred) and variability (high positive loadings of annCV and $\mathrm{HPC}$ ); and the third axis as a discharge axis (high positive loadings meanQ). 
Table 1. Principal component loadings for flow variables. Letters after variables refer to flow regime components (see Table 1): $\mathrm{v}=$ variability; $\mathrm{s}=$ seasonality; $\mathrm{p}=$ predictability.

\begin{tabular}{lccccccr}
\hline & \multicolumn{2}{c}{ Red Shiner } & \multicolumn{3}{c}{ Bluntnose Minnow } & \multicolumn{2}{c}{ Orangethroat Darter } \\
Variable & PC1 & PC2 & PC1 & PC2 & PC3 & PC1 & PC2 \\
& $(60.9 \%)$ & $(23.3 \%)$ & $(31.5 \%)$ & $(28.8 \%)$ & $(16.9 \%)$ & $(39.4 \%)$ & $(35.8 \%)$ \\
\hline meanQ & -0.329 & -0.357 & & -0.139 & 0.831 & & 0.481 \\
annCV (v) & -0.471 & 0.145 & 0.356 & 0.545 & -0.188 & -0.203 & -0.503 \\
HPC (v) & & -0.606 & 0.362 & 0.302 & 0.473 & -0.540 & -0.150 \\
BFI (p) & 0.477 & & 0.250 & -0.616 & -0.110 & 0.518 & -0.169 \\
FlowPred (p) & 0.450 & -0.283 & 0.365 & -0.428 & & -0.554 & \\
HPD (s) & -0.199 & -0.629 & -0.461 & -0.131 & -0.111 & -0.269 & 0.507 \\
Const/Pred (s) & 0.447 & & 0.573 & -0.113 & -0.152 & -0.129 & -0.456 \\
\hline
\end{tabular}

Table 2. Principal component loadings for life history variables. All life history variables were size-corrected and ln-transformed.

\begin{tabular}{lrrrrrr}
\hline & \multicolumn{2}{c}{ Red Shiner } & \multicolumn{2}{c}{ Bluntnose Minnow } & \multicolumn{2}{c}{ Orangethroat Darter } \\
Variable & PC1 (69.4\%) & PC2 (24.5\%) & PC1 (42.2\%) & PC2 (32.2\%) & PC1 (56.4\%) & PC2 (36.1\%) \\
\hline Ln(Fecundity) & 0.45307 & 0.88082 & 0.469583 & 0.785903 & 0.711943 & 0.192302 \\
Ln(Egg Size) & -0.61532 & 0.420524 & -0.68203 & 0.033548 & -0.70099 & 0.25179 \\
Ln(min SL @ & & & & & & \\
maturity) & 0.645063 & -0.21752 & 0.560647 & -0.61744 & 0.041746 & 0.948484
\end{tabular}




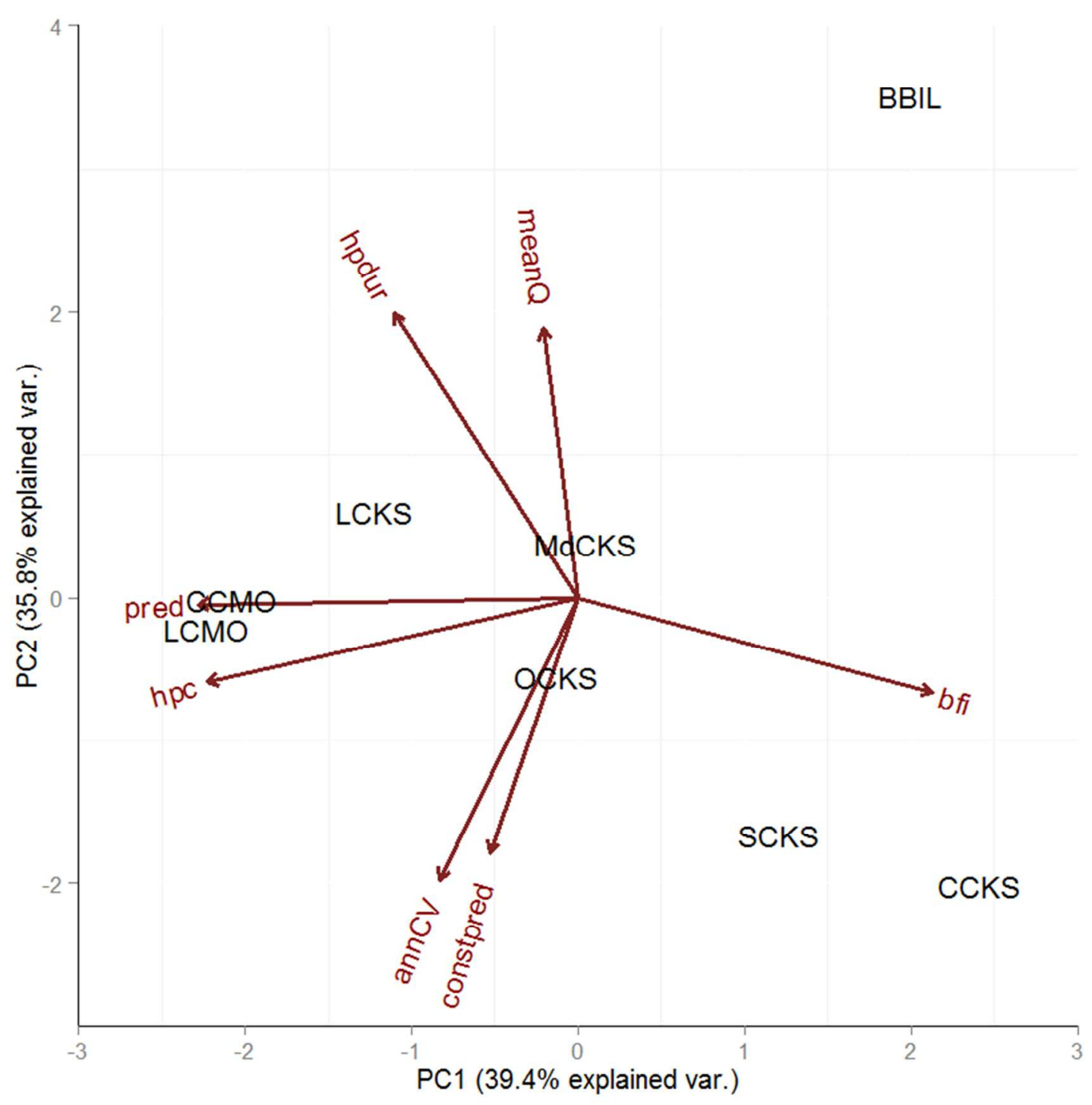

Figure 1. Flow PCA for Orangethroat Darter. Black text shows site scores. Red arrows and text highlight flow variable vectors. 


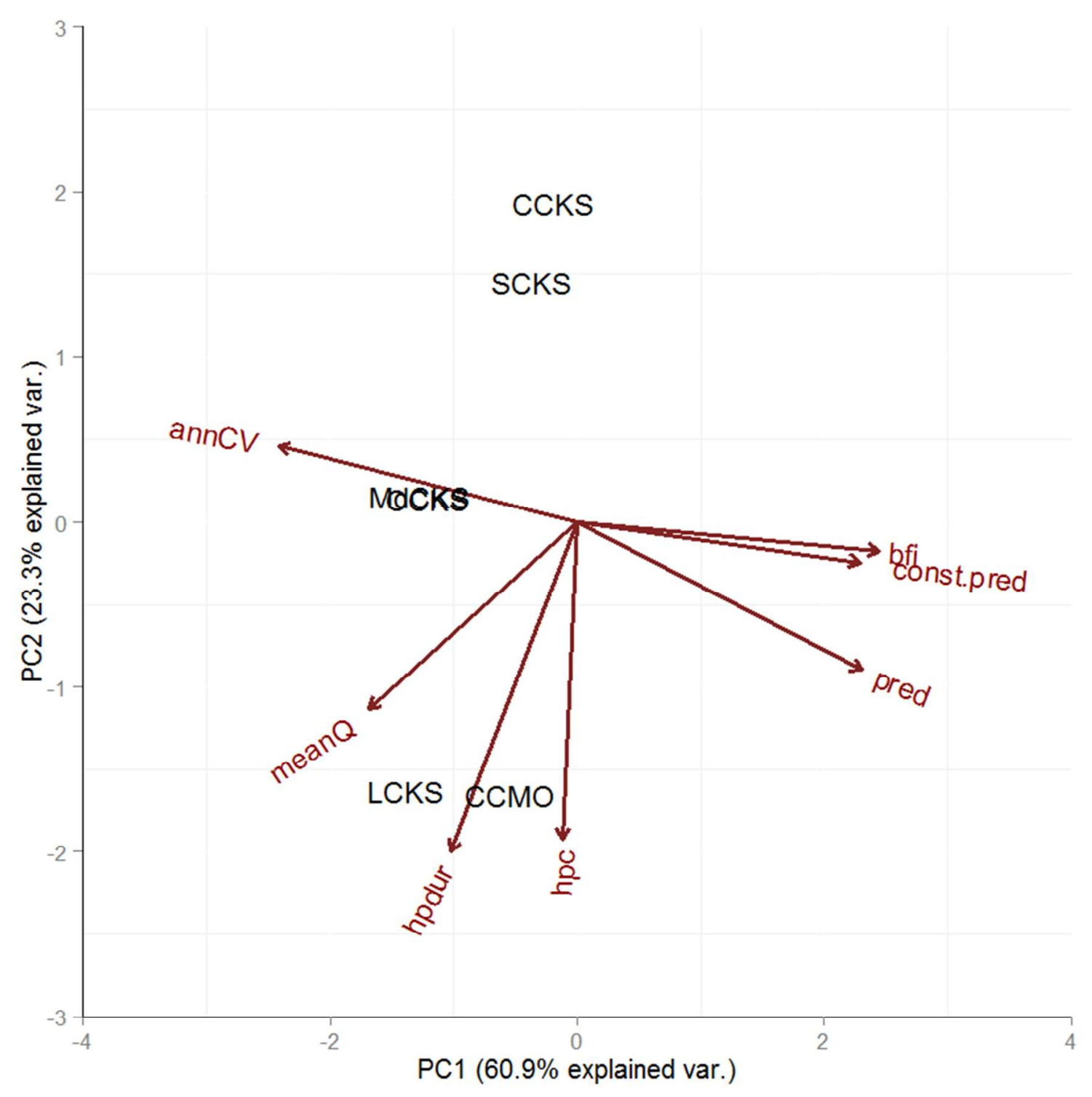

Figure 2. Flow PCA for Red Shiner. Black text shows site scores. Red arrows and text highlight flow variable vectors. 

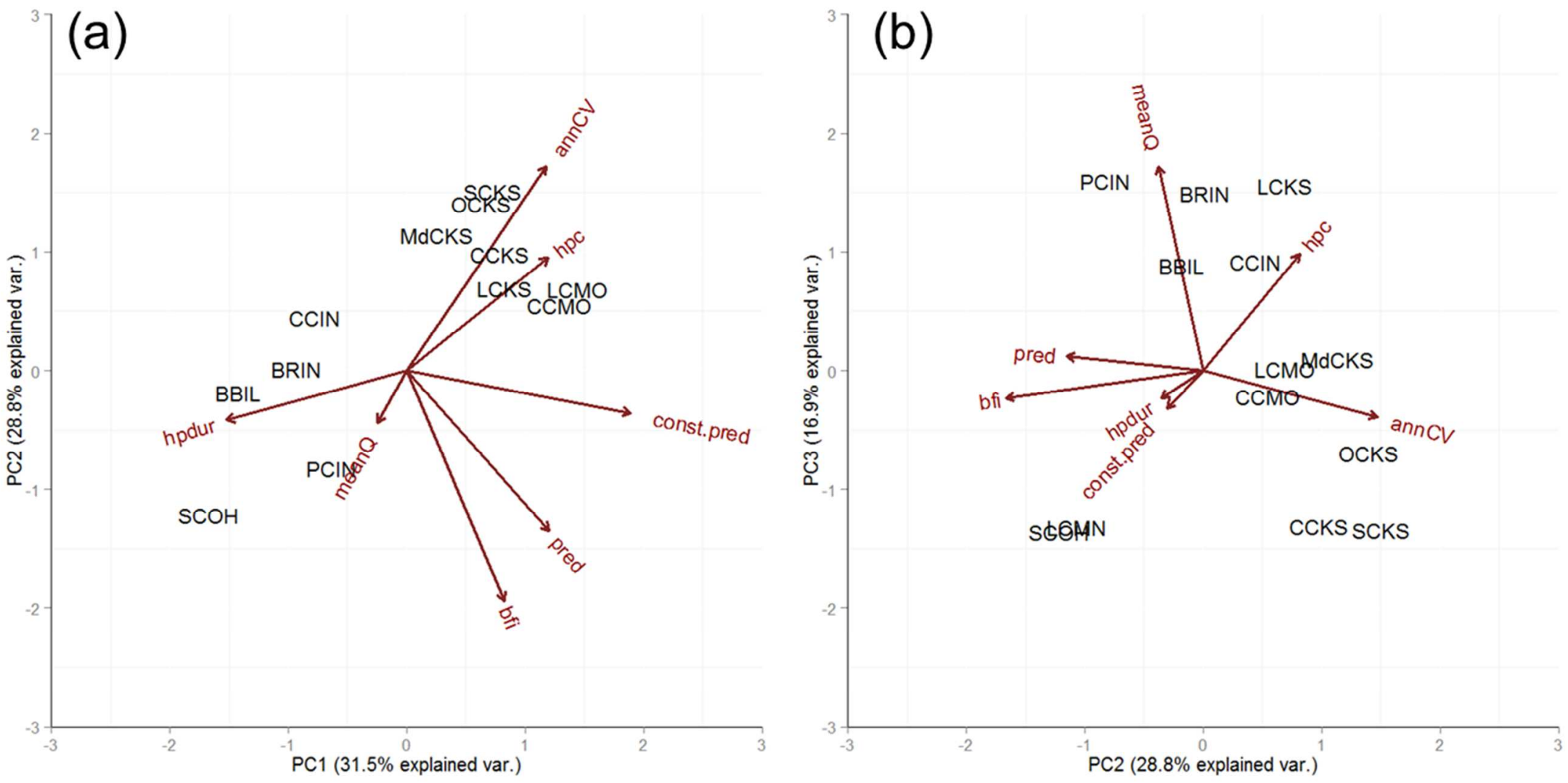

Figure 3. Flow PCAs for Bluntnose Minnow. (a) Flow PC1 (x axis) versus flow PC2 (y axis); (b) Flow PC2 (x axis) versus flow PC3 (y axis). Black text shows site scores. Red arrows and text highlight flow variable vectors. 
Appendix S5. Data on life history trait variability among populations.

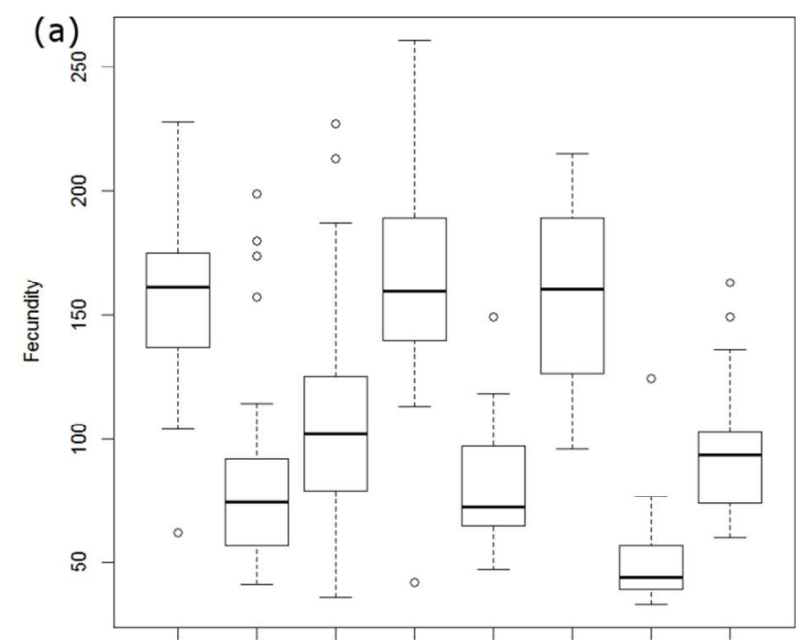

BBIL CCKS CCMO LCKS LCMO MdCKS OCKS SCKS

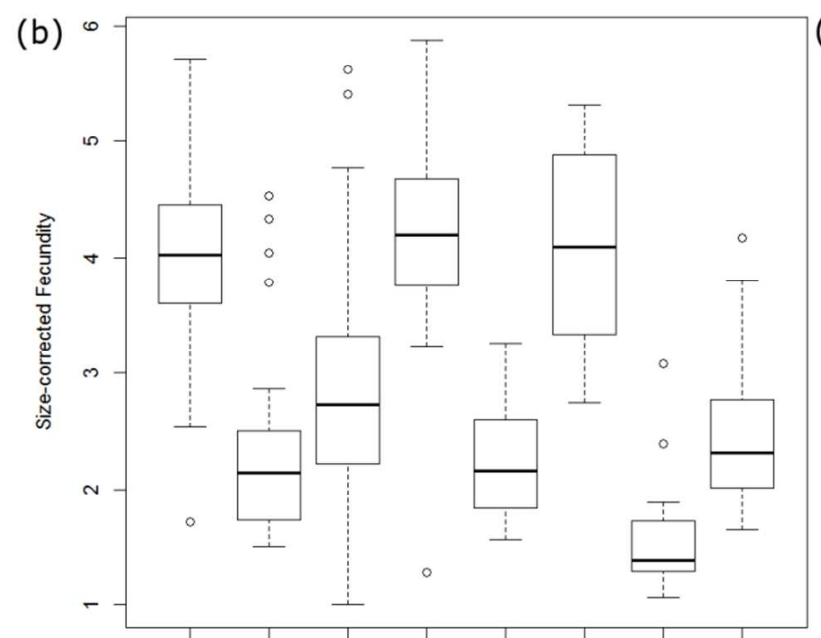

BBIL CCKS CCMO LCKS LCMO MdCKS OCKS SCKS

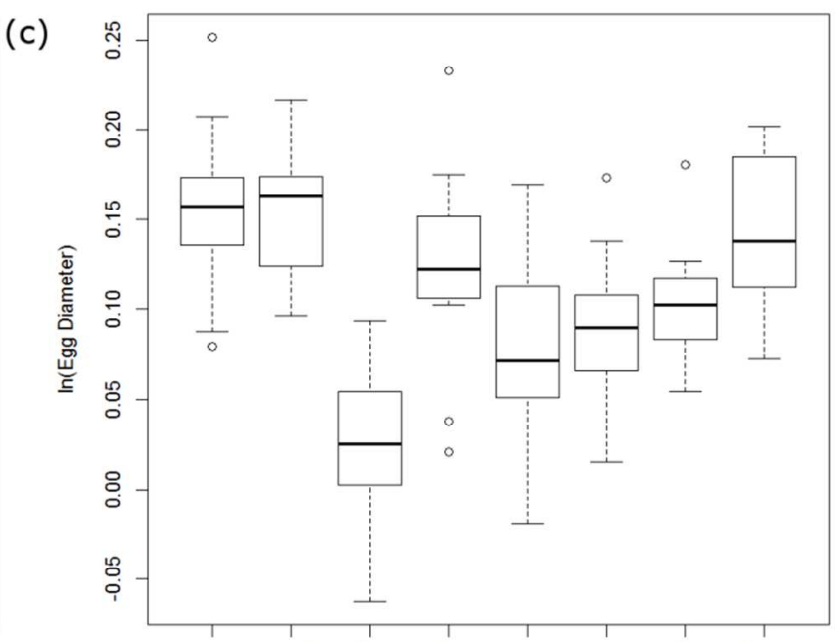

BBIL CCKS CCMO LCKS LCMO MdCKS OCKS SCKS
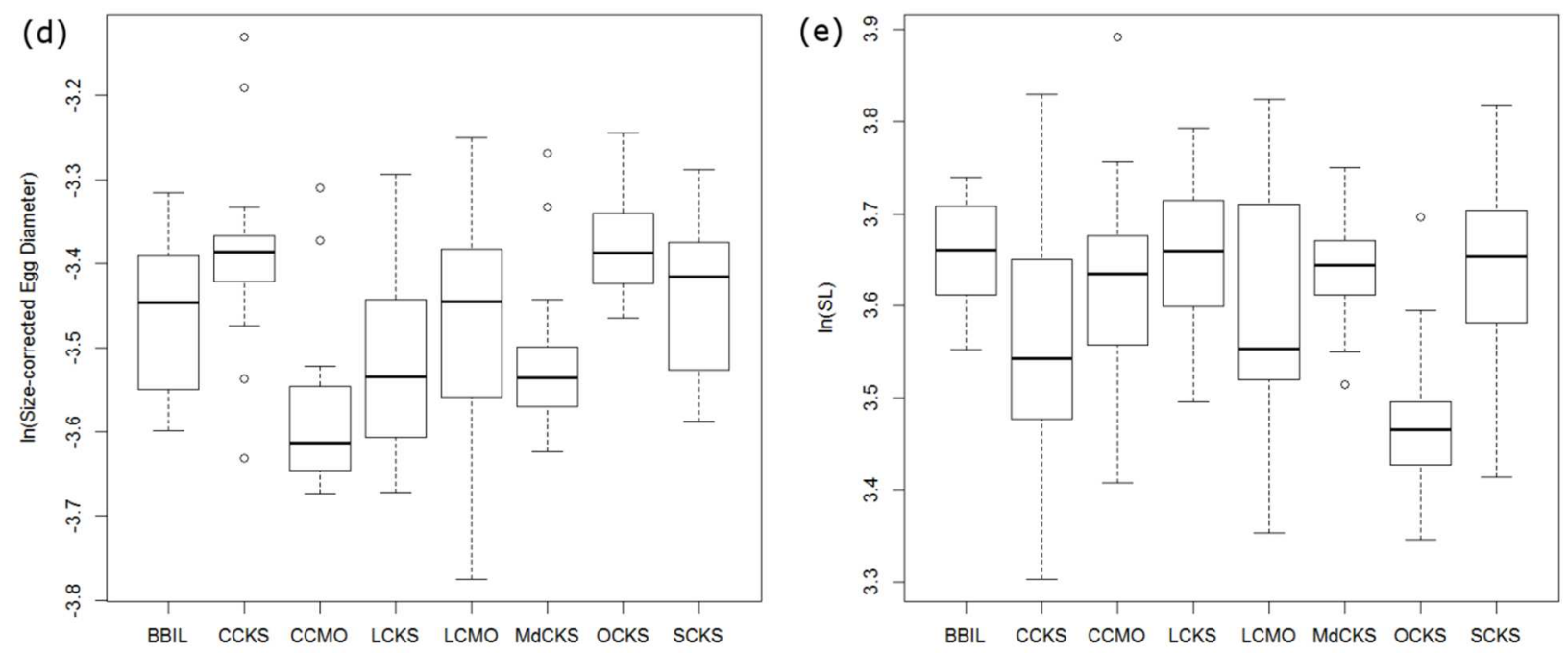

Figure S1. Boxplots showing variation in key traits among populations of orangethroat darter. (a) un-transformed fecundity, (b)size-corrected fecundity, (c) ln-transformed egg size, (d) ln-transformed size-corrected egg size, (d)ln-transformed standard length (SL). Box represents lower and upper quartiles ( $25 \%$ and $75 \%$, respectively) and black line represents median (50\% quartile). Whiskers represent $1.5 x$ the box length, with outliers shown. 

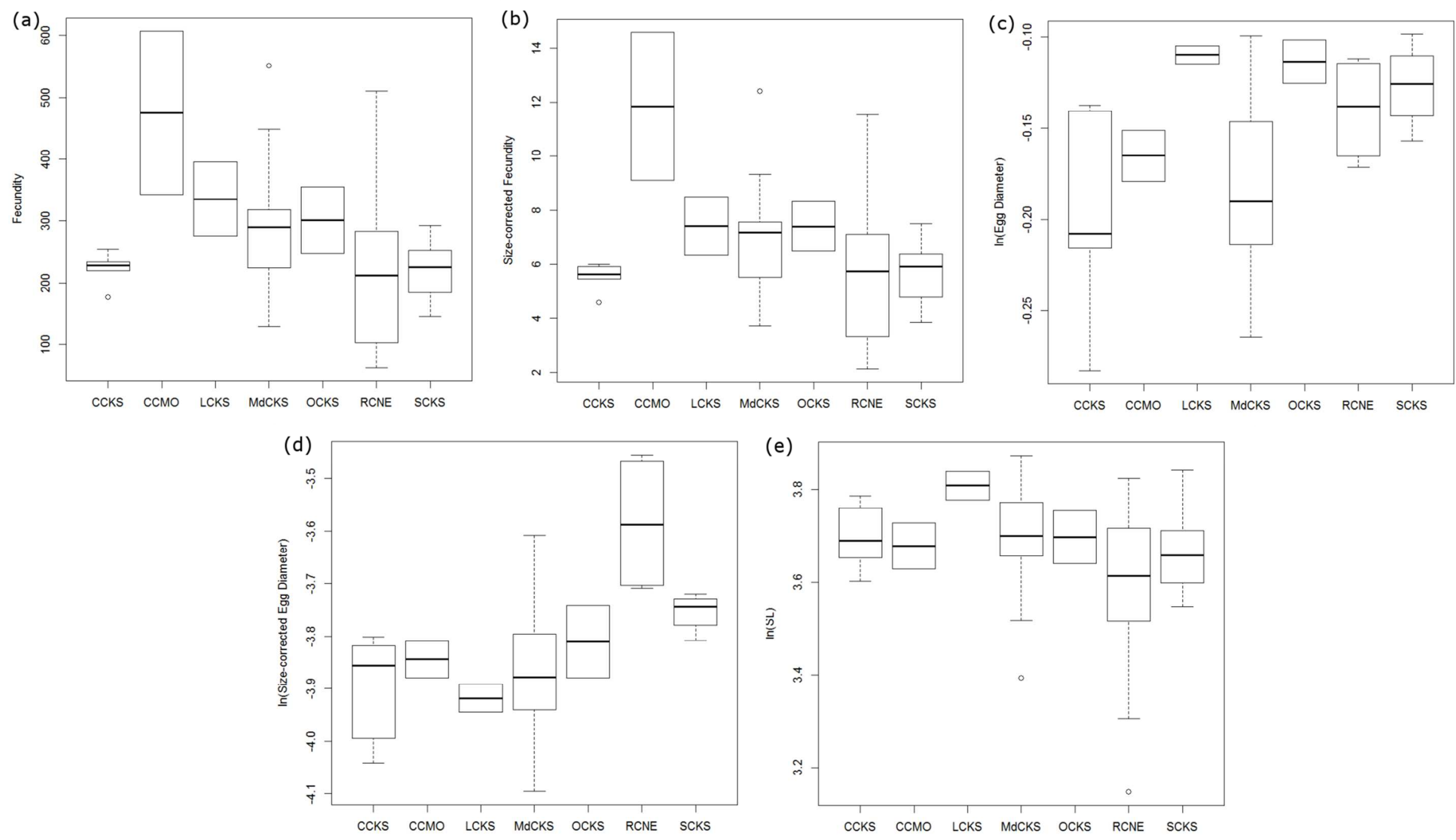

Figure S2. Boxplots showing variation in key traits among populations of red shiner. (a) un-transformed fecundity, (b)size-corrected fecundity, (c) lntransformed egg size, (d) ln-transformed size-corrected egg size, (d)ln-transformed standard length (SL). Box represents lower and upper quartiles ( $25 \%$ and $75 \%$, respectively) and black line represents median (50\% quartile). Whiskers represent $1.5 \mathrm{x}$ the box length, with outliers shown. 

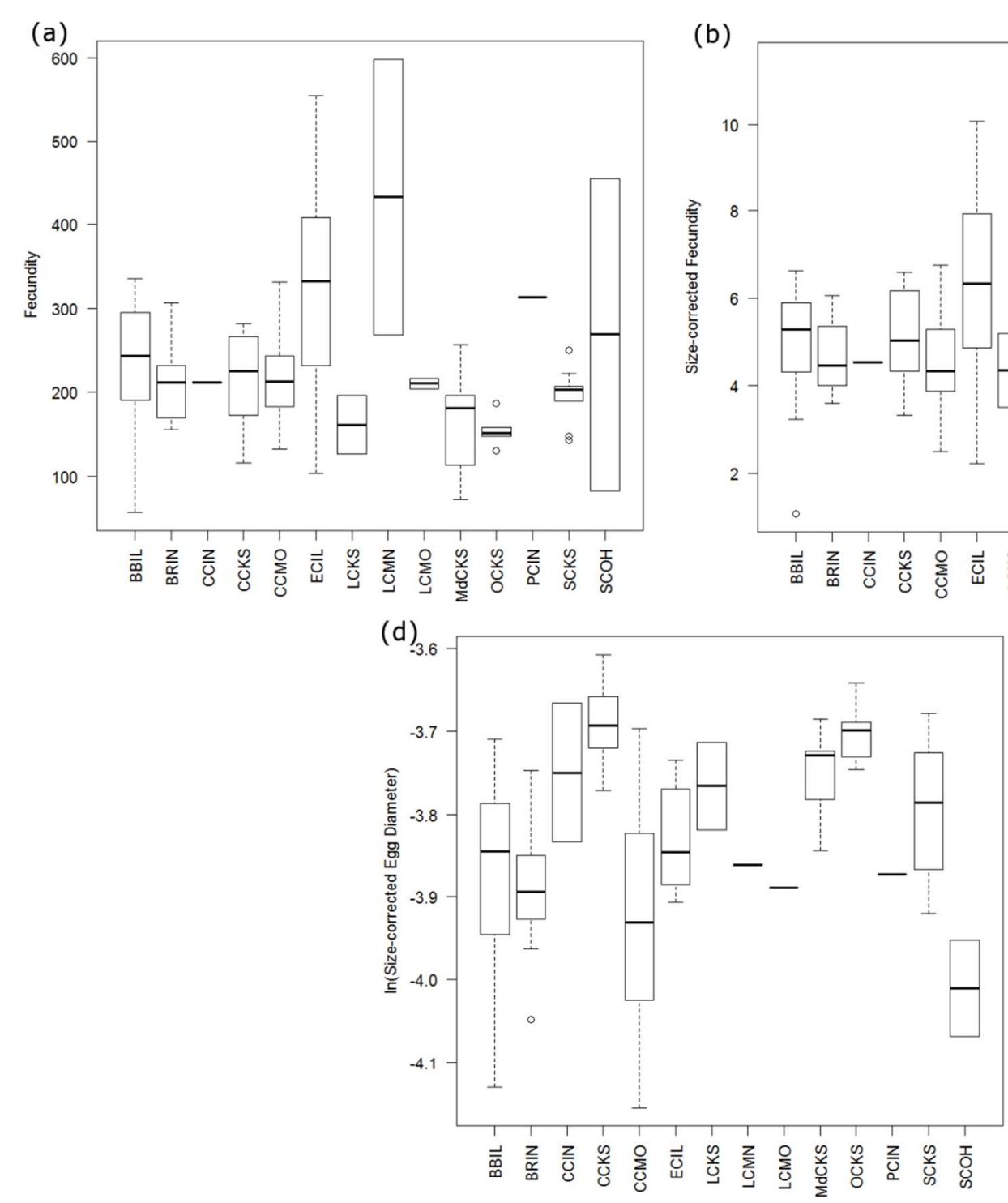

(b)

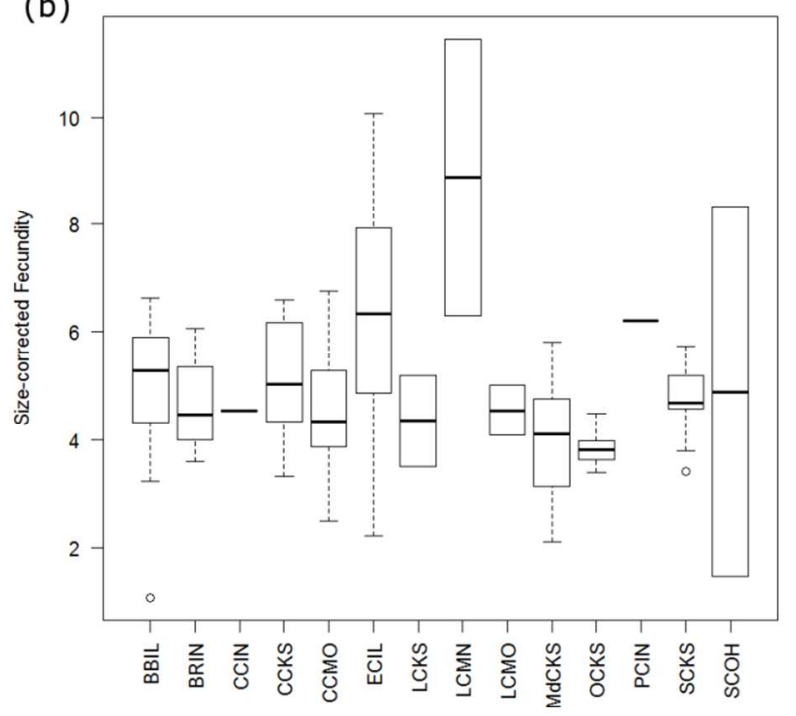

(c)

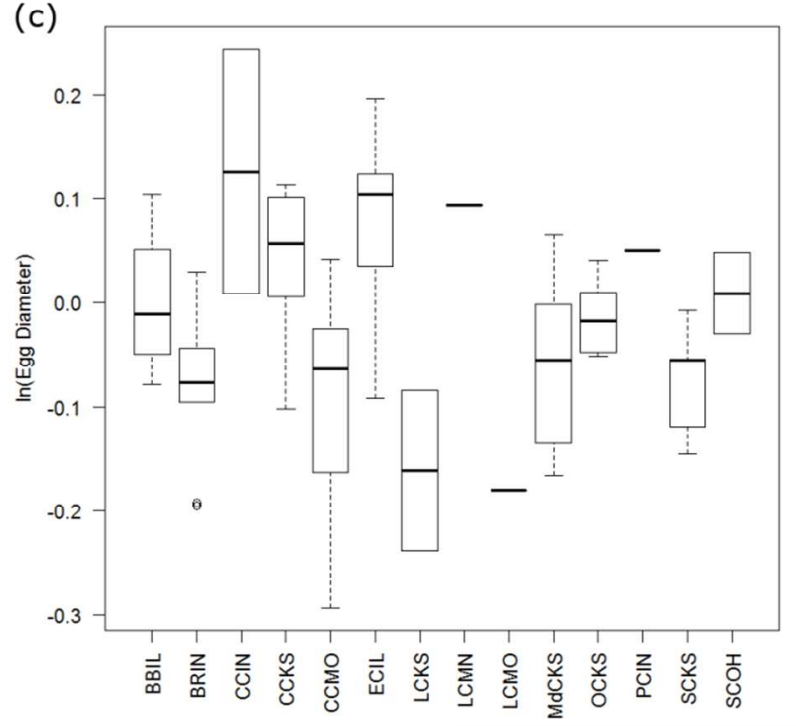

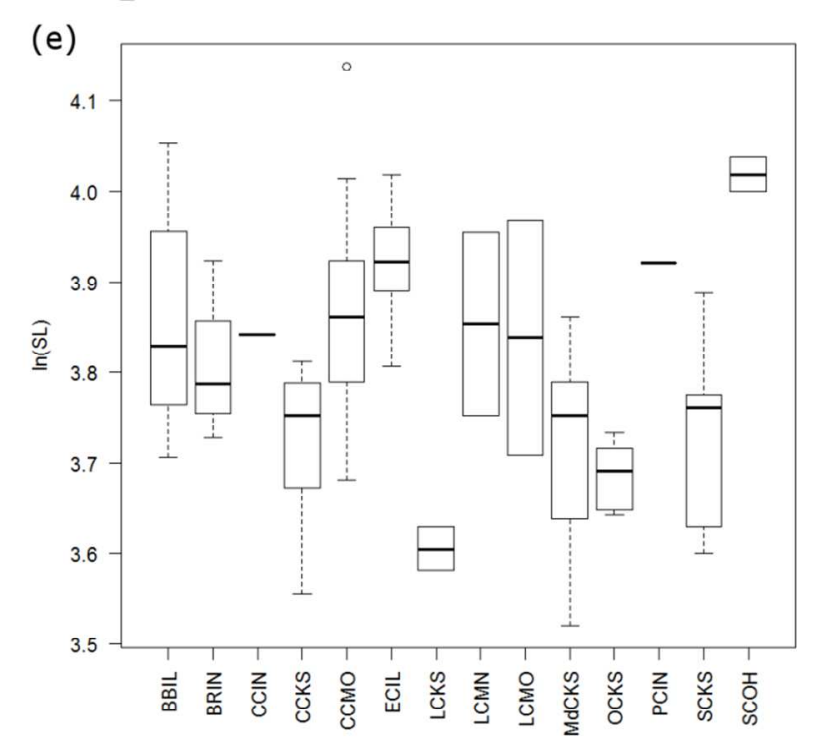

Figure S3. Boxplots showing variation in key traits among populations of bluntnose minnow. (a) un-transformed fecundity, (b)size-corrected fecundity, (c) ln-transformed egg size, (d) ln-transformed size-corrected egg size, (d)ln-transformed standard length (SL). Box represents lower and 
upper quartiles ( $25 \%$ and $75 \%$, respectively) and black line represents median (50\% quartile). Whiskers represent $1.5 \mathrm{x}$ the box length, with outliers shown. 
Appendix S6. Comparison of slopes of linear trait-environment regressions for full datasets (data from all sites for each species included) and for datasets in which sites with small sample sizes ( $<4$ individuals available for estimating trait values for that population) were excluded. Variables from the top ranked models (within $\triangle \mathrm{AICc}=2$ of lowest $\mathrm{AICc}$ ) and were selected for comparison of full datasets to those with small sample size sites removed. Slopes of relationships were consistent in direction and generally similar in magnitude compared to results from the full dataset except for a positive relationship between flow PC1 (negative: seasonality) and fecundity in bluntnose minnow in the dataset with small samples removed.

\begin{tabular}{|c|c|c|c|c|}
\hline \multirow[t]{2}{*}{ Species } & \multirow[t]{2}{*}{ Life history trait } & \multirow[t]{2}{*}{ Environmental variable } & \multirow{2}{*}{$\begin{array}{l}\text { Slope: } \\
\text { Full dataset }\end{array}$} & \multirow{2}{*}{$\begin{array}{l}\text { Slope: } \\
\text { Small removed }\end{array}$} \\
\hline & & & & \\
\hline \multirow[t]{4}{*}{ Red shiner } & Fecundity & Flow PC2 & -0.14 & -0.05 \\
\hline & Egg size & Flow PC1 & +0.05 & +0.04 \\
\hline & & Latitude & +0.08 & +0.11 \\
\hline & MinSLmat & Flow PC1 & -0.05 & -0.04 \\
\hline \multirow[t]{6}{*}{ Bluntnose minnow } & Fecundity & Flow PC1 & -0.09 & +0.05 \\
\hline & & Flow PC2 & -0.14 & -0.10 \\
\hline & & Latitude & +0.12 & +0.10 \\
\hline & Egg size & Flow PC2 & +0.02 & +0.02 \\
\hline & & Latitude & -0.02 & -0.04 \\
\hline & MinSLmat & Flow PC3 & +0.03 & +0.02 \\
\hline
\end{tabular}


Figure 1. The trilateral life history framework of Winemiller and Rose (1992). Modified from Winemiller (2005) and Mims and Olden (2012). $254 \times 190 \mathrm{~mm}(96 \times 96 \mathrm{DPI})$ 
Figure 2. Map of study sites where mature (mature, ripening, or ripe) specimens of target species were found. For site codes and information, see Appendix S1. $111 \times 74 \mathrm{~mm}(600 \times 600$ DPI $)$ 

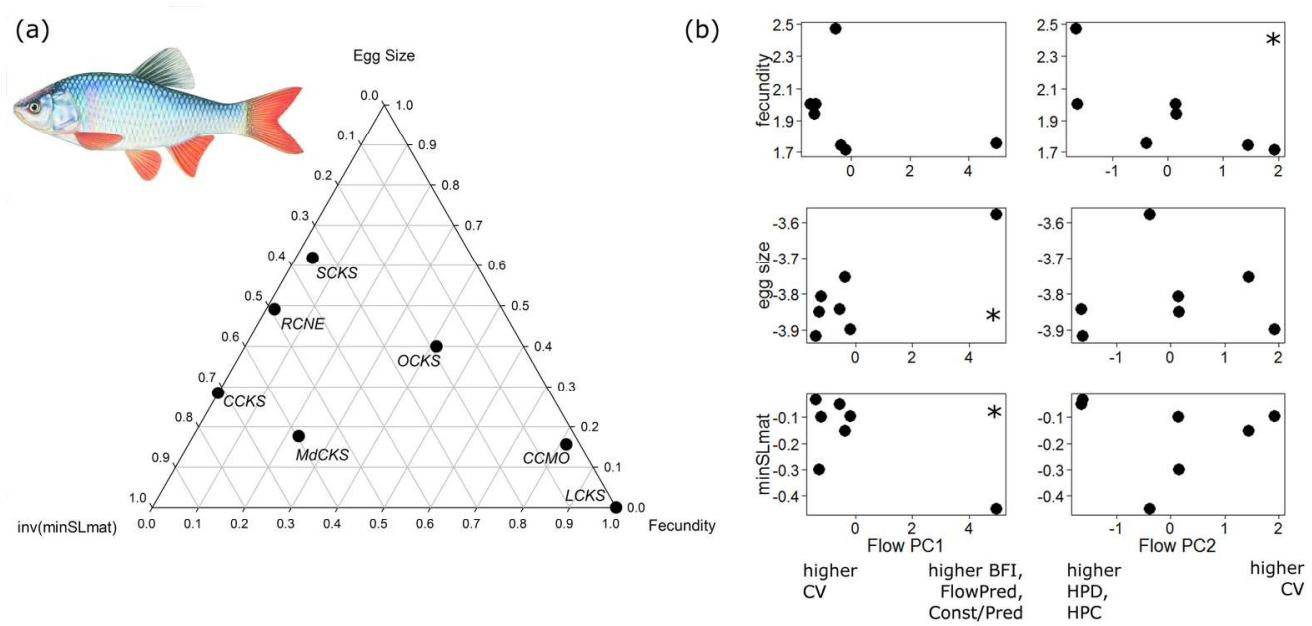

Figure 3. Population life history strategies and flow-trait relationships for red shiner. (a) Ternary plot illustrating trade-offs in traits among populations. Axes scaled between 0 and 1 for the three traits (bottom axis: fecundity; right axis: egg size; left axis: inverse(minSLmat)). Solid circles represent study sites (see Appendix S1). (b) Scatterplots of flow PC-trait relationships. Asterisk indicates important relationship from multiple regression results (Table 2). Higher values of flow PC1 (lower CV), in left panels, were associated with larger eggs and smaller size at maturity. Higher values of flow PC2 (lower HPC, HPD, higher CV), on right panels, were associated with lower fecundity. Illustration of male red shiner copyright and used with permission of Joseph R. Tomelleri. $175 \times 86 \mathrm{~mm}(300 \times 300 \mathrm{DPI})$ 
(b)
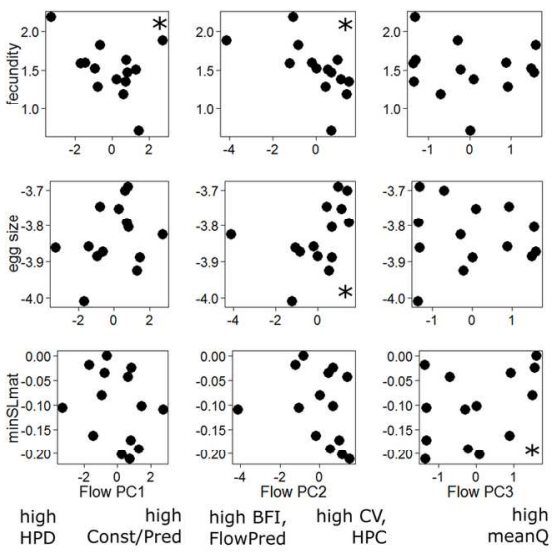

Figure 4. Population life history strategies and flow-trait relationships for bluntnose minnow. (a) Ternary plot illustrating trade-offs in traits among populations. Axes scaled between 0 and 1 for the three traits (bottom axis: fecundity; right axis: egg size; left axis: inverse(minSLmat)). Solid circles represent study sites (see Appendix S1). (b) Scatterplots of flow PC-trait relationships. Asterisk indicates important relationship from multiple regression results (Table 2). Higher values of flow PC1 (lower HPD, higher ConstPred), in left panels, were associated with lower fecundity. Higher values of flow PC2 (higher CV, HPC; lower BFI), in middle panels, were associated with lower fecundity and larger egg size. Higher values of flow PC3 (higher meanQ), right panels, were associated with larger size at maturity. Illustration of male bluntnose minnow copyright and used with permission of Joseph R. Tomelleri. $156 \times 69 \mathrm{~mm}(300 \times 300 \mathrm{DPI})$ 
1

2

3

4

5

6

7

8

9

10

11

12

13

14

15

16

17

18

19

20

21

22

23

24

25

26

27

28

29

30

31

32

33

34

35

36

37

38

39

40

41

42

43

44

45

46

47

48

49

50

51

52

53

54

55

56

57

58

59

60 (a)

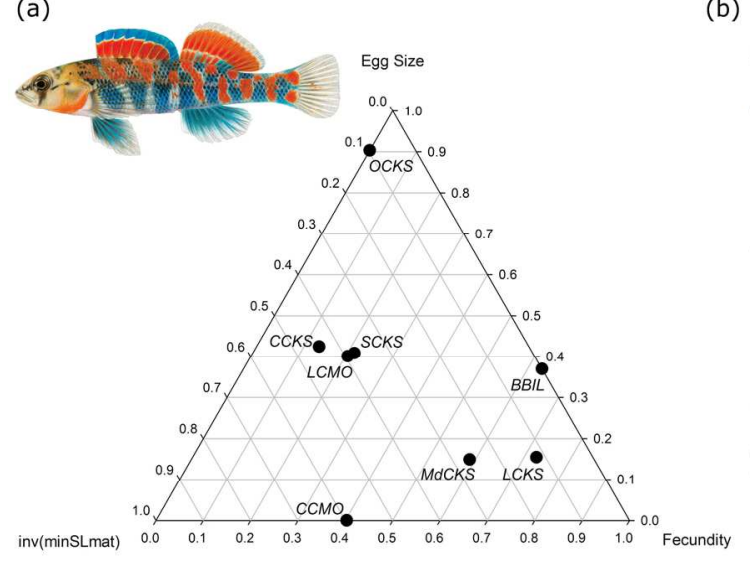

(b)
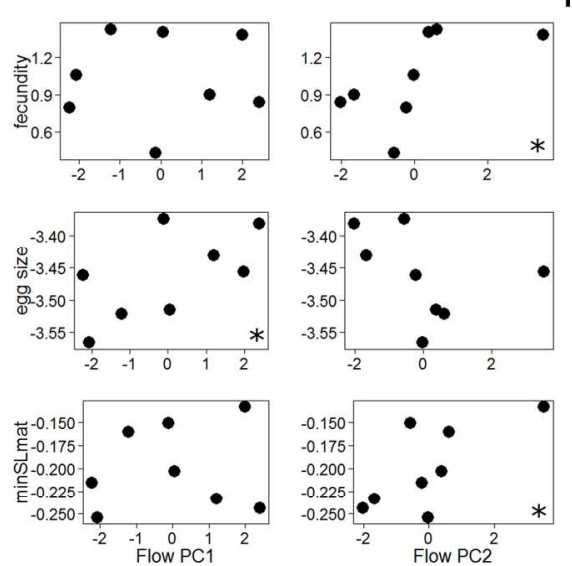

high FlowPred, high BFI

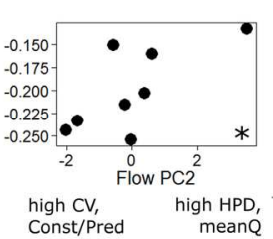

Figure 5. Population life history strategies and flow-trait relationships for orangethroat darter. (a) Ternary plot illustrating trade-offs in traits among populations. Axes scaled between 0 and 1 for the three traits (bottom axis: fecundity; right axis: egg size; left axis: inverse(minSLmat)). Solid circles represent study sites (see Appendix S1). (b) Scatterplots of flow PC-trait relationships. Asterisk indicates important relationship from multiple regression results (Table 2). Higher values of flow PC1 (higher BFI, lower HPC) were associated with larger eggs. Higher values of flow PC2 (higher HPD, lower CV) were associated with higher fecundity and larger size at maturity. Illustration of male orangethroat darter (E. spectabile pulchellum) copyright and used with permission of Joseph R. Tomelleri.

$166 \times 79 \mathrm{~mm}(300 \times 300 \mathrm{DPI})$ 

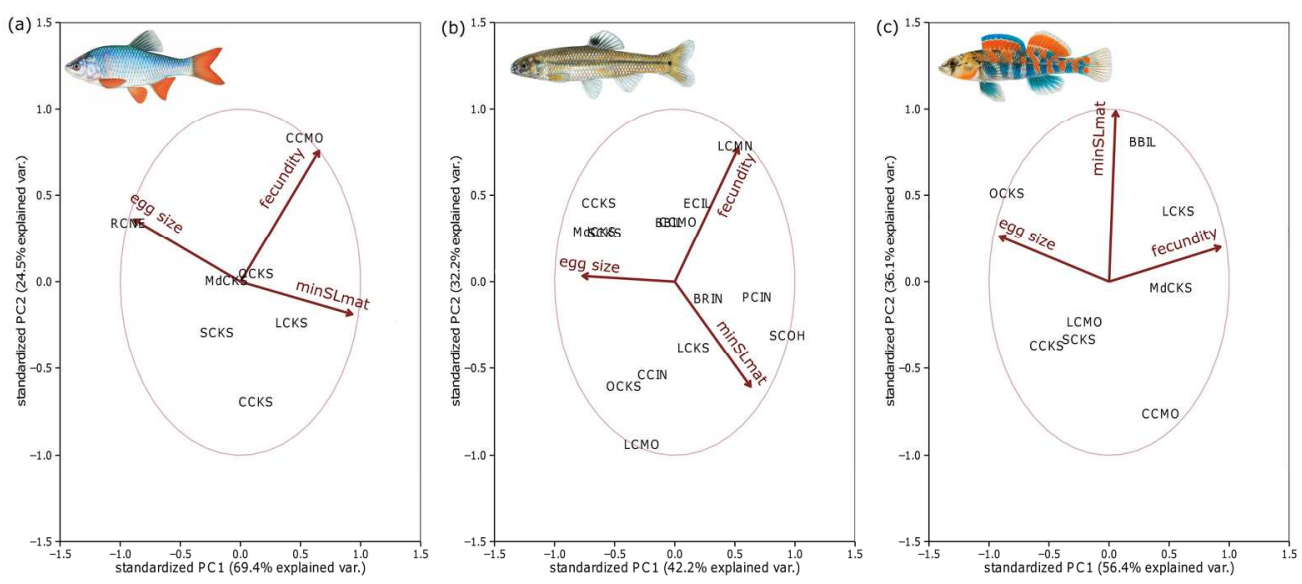

Figure 6. Principal component plots for life history traits for (left to right) red shiner, bluntnose minnow, and orangethroat darter. We interpreted PC1 as an equilibrium (negative) to periodic (positive) axis for all species. We interpreted PC2 as an opportunistic (around zero) to periodic (positive or negative) axis for all species. Red text associated with arrows identifies trait vectors (In-transformed, size-corrected traits). Uppercase black text identifies site scores (see Appendix S1). Fish illustrations copyright and used with permission of Joseph R. Tomelleri. $177 \times 79 \mathrm{~mm}(300 \times 300 \mathrm{DPI})$ 